Portland State University

PDXScholar

5-5-1975

\title{
Attendance at Out-Patient Clinics as a Function of Risk Taking for Alcoholics
}

John Ketcham Fryer

Portland State University

Follow this and additional works at: https://pdxscholar.library.pdx.edu/open_access_etds

Part of the Social Work Commons

Let us know how access to this document benefits you.

\section{Recommended Citation}

Fryer, John Ketcham, "Attendance at Out-Patient Clinics as a Function of Risk Taking for Alcoholics" (1975). Dissertations and Theses. Paper 1960.

https://doi.org/10.15760/etd.1959

This Thesis is brought to you for free and open access. It has been accepted for inclusion in Dissertations and Theses by an authorized administrator of PDXScholar. Please contact us if we can make this document more accessible: pdxscholar@pdx.edu. 
AN ABSTRACT OF THE THESIS. OF John Ketcham Fryer for the Master of Social Work presented May 5, 1975. Title: Attendance at Out-Patient Clinics as a Function of Risk Taking For Alcoholics.

APPROVED BY MEMBERS OF THE THESIS COMMITTEE:

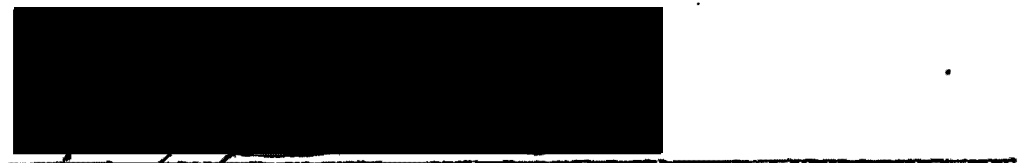

Frank F. Mlles, Chalrman

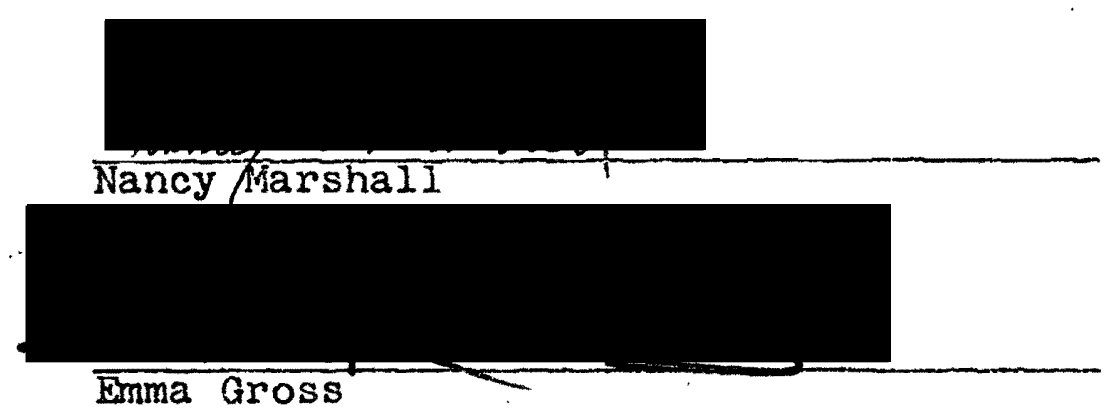

Sixty hospltalized male and female alconolies were given the Kogan-Wallach Choice D1lemmas Questionnaire (1964) upon admission to an in-patient alcohol treatment program and just prior to discharge.

Scorea were eliclted from the questionnaire to measure three aspects of risk taking in decision making: 1) Probabilities or odds of success, 2) tolexance of amblguity, and 3) preference for sure bets.

Risk data was related to attendance at out-patient clinlcs after discharge from the program. Analysis of data 
was conducted by dividing the sample into two groups defined by attendance at the out-patient clinics.

It was hypothesized that subjects attending the outpatient clinics would show larger changes in the direction of increased risk taking between pre and post-program testIng conditions, and that their scores would be lower numerically, indicating a greater willingness to take risks.

Change in the direction of increased risk taking was found to be the major predictor of attendance at the outpatient clinics. Absolute willingness to risk, as measured by the questionnaire was not found to be significantly different between the two groups. 
ATTENDANCE AT OUT-PATIENT CLINICS AS A

FUNCTION OF RISK TAKING FOR

\section{ALCOHOLICS}

by

JOHN KETCHAM FRYER

A thesis submitted in partial fulfiliment of the requirements for the degree of

MASTER OF SOCIAL WORK

Portland State University

1975 
TO THE OFFICE OF GRADUATE STUDIES AND RESEARCH:

The members of the Committee approve the thesis of John Ketcham Fryer presented May 5, 1975.

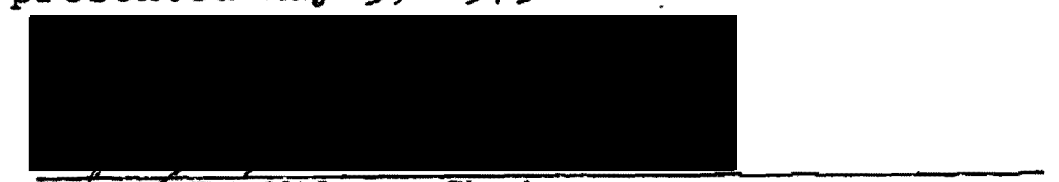

Frank. Miles, Chairman

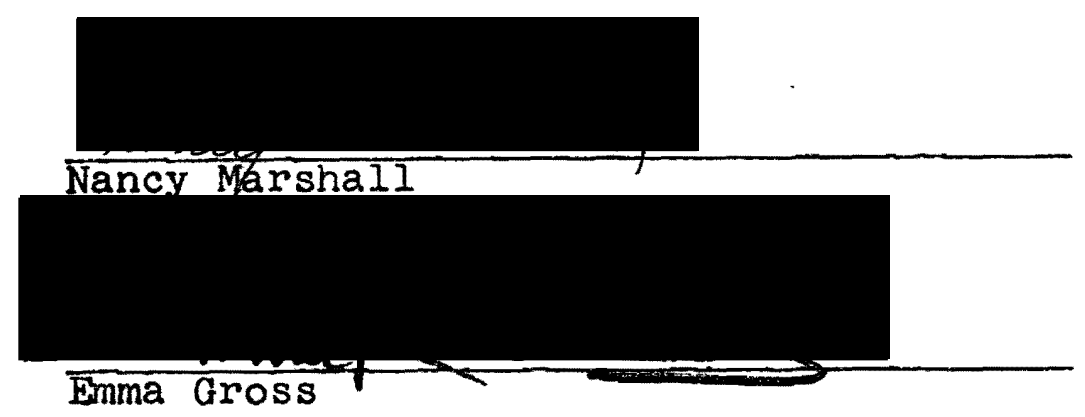

APPROVED :

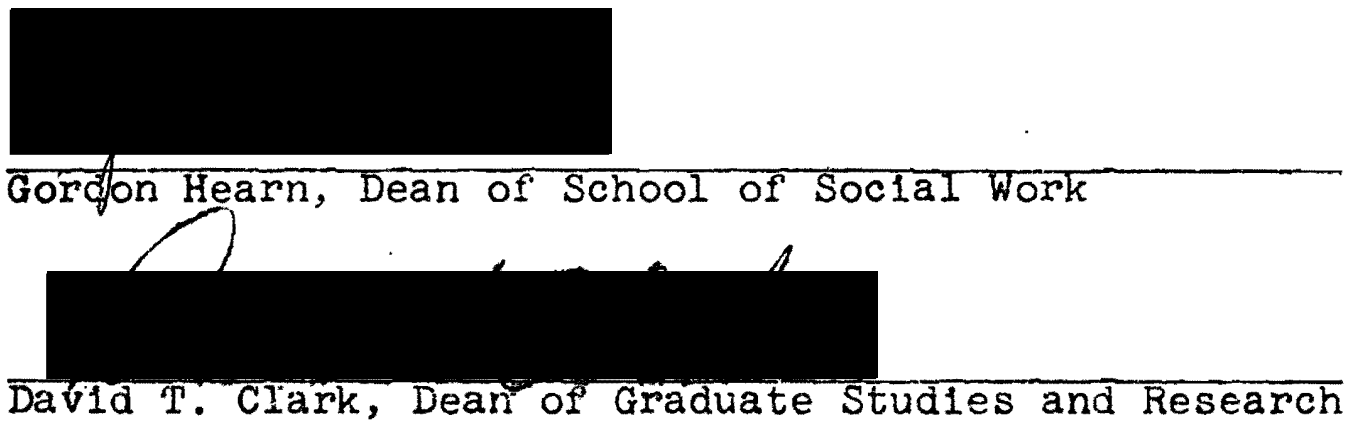

May 12, 1975 


\section{ACKNOWLEDGMENTS}

A large number of people have contributed to the culmination of this research. My thesis committee has been understanding, tolerant and helpful during all phases of the endeavor and so speclal thanks to Frank Miles, Nancy Marshall and Emma Gross. I would also like to thank the entire staff of the Dammasch Hospital Alcohol Treatment Program for their timely advice and assistance in collecting the data. In particular, David Nichols, Eric Bergmark and Ed Buckman were especlally helpful. Above all, thanks are in order for my wife Judy, who listened to months of moaning and groaning without once considering divorce. 
TABLE OF CONTENTS

PAGE

ACKNOWLEDGMENTS . . . . . . . . . . . . . . 111

LIST OF TABLES . . . . . . . . . . . . . . . v1

CHAPTER

I INTRODUCTION . . . . . . . . . . . 1

Definition of Risk Taking . . . . . 4

Alcohol $1 \mathrm{sm}$. . . . . . . . . . 13

II REVIEW OF LITERATURE . . . . . . . . . 22

III METHODS . . . . . . . . . . 36

Procedure . . . . . . . . . . 36

Risk-Taking Instrument :. . . . . 38

The Therapy Program.......... 41

Attendance as Change . . . . . . . 44

Analysis . . . . . . . . . . 45

Operational Definitions: . . . . 47

Hypotheses ............ 50

Definition of Symbols . . . . . . . 52

IV RESULTS AND DISCUSSION . . . . . . . . 53

Section 1............. . 53

Section 2............. 64

Section 3............. 66

Summary of Results . . . . . . . 72

V CONCLUSION . . . . . . . . . 74

Research Difficulties....... . 74

Recommendations for. Further Research : 74

Implications . . . . . . . . . 75 
PAGE

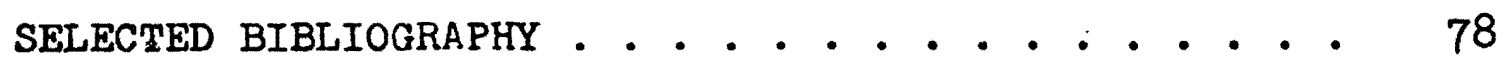
APPENDIX . . . . . . . . . . . . . . . . . 83 


\section{LIST OF TABLES}

TABLE

PAGE

I Mean R1sk Scores for Follow-up Group . . . . 54

II Mean Risk Scores for Non Follow-up Group . . 55

III Mean Change Scores for Risk Measures in

FU and NFU Groups ........ . . 56

IV Post-Program Risk Means for FU and NFU Groups ........... . . 57

$\mathrm{V}$ Change Scores for Risk Measures in

MMPI Categories.......... . . 58

VI Mean Risk Scores by Age for PrPT and

POPT . . . . . . . . . . . 59

VII Mean Risk Scores by Days for PrPT and

POPT ................ 61

VIII Mean Risk Scores for Men and Women in

PrPT and PoPT . . . . . . . . . 63

IX Mean Change for Men and Women Between

PrPT and PoPT ........... 64

$X$ R1sk Scores for FU and NFU Groups in

Sequence ........... 67 
CHAPTER I

INTRODUCTION

Many psychotherapists feel that the capacity to risk is a necessary ingredient for change. Whether that change occur in a person seen in a professional context or in a person who views new behavior as being more rewarding, risk and change go hand in hand. Coleman (1972) described this relationship in the following way.

Life often poses problems in which the pursult of increased satisfactions involves giving up present hard-won security and taking new risks. For the neurotic, this is likely to prove an especially anxiety-arousing conflictful situation [p. 226$]$.

Why should this be true? It seems that one of the major ways we keep ourselves from risking is by requiring knowledge of what is going to happen before we will try something new. Polster and Polster (1972) state:

For most people the need to be able to predict the results of their actions prevents them from easily reaching beyond the existing forms of behavior where the greatest opportunities are present. If they venture into unfamiliar territory, while they might gain an increased sense of excitement and power, they might lose their easy understanding and feel unprepared and alien [p. 148].

Another force which makes risking, for change, a difficult process is the fear of knowledge of oneself. Fart of our energy is directed towards malntaining and protecting 
our self-esteem. We tend to be afraid of information that may undermine our Ideal image and use repressive defenses to avold coming in contact with what are percelved as unpleasant truths.

Maslow (1968) argues that there are two ways of dealing with the unknown. One is to move toward knowledge and increased understanding of oneself. This is the growth process, by which one comes to know new aspects of himself and can decide whether or not the behavior or characteristic is positive. Another way of dealing with the unknown is by clinging to safety and defensiveness. Here the person hangs on to the past, afraid to jeopardize what he already has, thereby blindly supporting and defending the old belief. Maslow (1968) describes the process of healthy growth as tions, confronting each individual at every point
throughout his ilfe, in which he must choose between
the delights of safety and growth [p. 47$]$. Each of the situations Maslow refers to requires a decision in which the adaptiveness of old behavior is welghed against the risk of trying something new. In a therapeutic context, trying something new (change) involves learning and practicing new skills. Polster and Polster (1972) state: 
A skill cannot be learned well until it is tried out. By trying it out, the individual lowers his threshold of risk. In fact, the whole therapy scene is almed at altering risk thresholds through trying out in relatively safe situations what is prohibitively frightening in the world outside [p. 108$]$.

Another aspect of therapy is developing awareness or insight and here again we run into the need for risk taking. Enright (1971) describes new awareness as almost always following a sense of taking a chance:

- . of groping to say the unsayable or beginning something without being sure of the ending. When this experience is not present, almost certainly the "Insight" being presented is a sterile rehash rather than an expansion of awareness [p. 119].

Risk taking seems to be an important aspect of healthy functioning and plays an integral part in changing maladaptive behaviors. Yet, even though these Ideas are generally accepted, the relationship between risk taking and healthy functioning, or change to healthier functioning, has been little tested empirically.

The focus of the present study is to investigate some of the relationships between changes on an empirical measure of risk taking and subsequent behavioral changes. The Kogan-Wallaxh Cholce Dilemmas Questionnaire (1964) is used as the empirical measure of risk and was given to hospltallzed alcoholics before and after an in-patient hospital treatment program. As a measure of behavioral change, attendance at out-patient clinics was chosen because 
continued participation on an out-patient basis has been related to reduced drinking and increased functioning in other areas of the alcoholic's life (Gerard and Saenger 1966). A detalled discussion of the attributes and Iimitations of these variables w1ll be presented later.

The remainder of the Introduction will be devoted to defining risk taking and discussing the present state of the art with reference to alcoholism.

Definttion of Risk Taking

Researchers on risk taking do not look at the concept of risk from quite the same perspective as do the above c1ted therapists and theorists. Their thinking is remarkably less romantic. For some, the concept of risk was not a necessary factor in predicting decision-making behavior.

Ddwards (1953), for example, proposed a group of models which postulated that a decision maker will choose the alternative which will yleld the maximum value for him. The decision is based on a logical cholce between the alternatives avallable: Emphasis is placed on the quality of the alternatives and not on the characteristics of the individual. Therefore, if behavior can be predicted by ignoring Individual differences or situational circumstances, the concept of risk becomes irrelevant. 
Experiments conducted by Edwards (1953, 1954a, 1954b and $1954 \mathrm{c}$ ) and Pruitt (1962) have demonstrated that decision making based solely on maximizing expected value does not account for a significant (30 to 45 per cent) portion of the variance. It can reasonably be assumed that other factors besldes logic and rationality, are involved in decision mak1ng. Therefore, the inclusion of risk as a factor in dec1sion making seems fustified.

What are some of the factors of decision making involving risk? Certainly one of the first factors to consider is the probablilty of achleving a successful outcome, 1.e., the odds. It is commonly assumed that low odds, that 1s, fewer chances of achleving a successful outcome, is characteristic of a risky decision. Therefore, based strictly on a consideration of the odds, decisions where the odds were low would be made less frequently or at least more cautiously than decisions where the odds were high. This would certainly be true if the decision were to bet ten dollars, where winning ylelded a ten dollar gain and losing resulted in a ten dollar loss. If, however, the bet were changed such that the loss of the wager resulted in add1tional penalties one might be less willing to accept the bet even though the odds were welghted toward a successful outcome. 
In addition to odds, then, potential gains versus costs constitutes the second major factor in decision making involving risk. Given Identical odds, e.g., five in ten, fach of the following sets of gains versus eosts may create different decisions whether to accept the risk or not :

\section{GAIN}

Missing a class.

$\$ 10,000.00$.

An evening with a nice person.

A new Job, with more money, prestige and. responsibility.

\section{$\operatorname{cosT}$}

Missing a "pop" quiz.

Ten years in prison.

Feelings of rejection.

Falling at the new job; or, success with ulcers.

Kogan and Wallach (1964) define risk in terms of two similar concepts: lack of certainty and the prospect of loss or fallure. Nelther of these two factors contributes equally to the general assessment of risk in decision making. Where odds may be critically important in a business venture, the prospect of loss or fallure may be more important in declding whether or not to go sky diving for the first time. Kogan and Wallach (1967) go on to define risk in the following way:

To talk about risk taking, then, is to refer to behavior in situations where there is a desirable goal and a lack of certainty that it can be attained. The situations may take the form of 
requiring a cholce between more and less desiraple goals, with the former having a lower probablilty of attainment than the latter. A further possible characteristic of such situations is the threat of negative consequences for fallure, so that the individual at the post decisional state might find himself worse of $f$ than he was before he made the decision [p. 115].

The above defintition of risk, where "desirable goal" and "lack of certainty" are major factors, cannot be applied to: the situation of risk in many contexts without modification. One characteristic of the definition is the implicit assumption that the thing being risked is in the decision maker's awareness; that is, in terms of the above definition that the desirable goal is known. Take for example, the dectsion by an adolescent of whether or not to accept a bet involving an illegal road race. In this situation the overt "destrable goal" is to win the race and therefore the bet. From a subfective level the desirable goal may be to accept the bet, Ilve through the race, and most importantly, avold the potential of being thought of as a "chicken." From this subfective point of view the teen-ager may be taking less $r$ lsk in racing than in declining. The degree of risk in this example seems to be a function of the individual's perception of what is at stake from both an objective and subJective point of view.

The potential for both objective and subjective loss is not strictly limited to the growing pains of adolescents. 
Another example may be helpful. Betty is a supervisor in a porly managed business. In this context she is called upon to make decisions of importance disproportionate to her position. She is asked to work overtime; she is not pald as much as she needs nor is worth; and the working conditions, both physically and emotionally, are terrible. She has been actively looking for a new Job and has been finally offered another position. The new job would be almost the exact reverse of her present position. She would recelve more money responsibility would be well-defined, working cond1tions are excellent and the managerlal staff has an excellent neputation.

Will she take the new Job? It seems likely if money, working conditions, and managerial structure are the major factors in her emotional scheme of things. Yet there could be other factors which would make moving to the other job a risky proposition.

One thing that Betty could risk in moving to the new job is her sense of competence. In a poorly managed company Betty is clearly a competent and Important person, at least in comparison to the other staff. The risk involved in changing Jobs is in finding out whether that sense of competence will carry over to the new job.

From an existential standpoint the risks for the teenager and Betty are straightforward and therefore significant. 
The teen-ager is risking his fledgling conception of manhoiod. His decision may be based less on the maintenance of Iffe than on the maintenance of his conception of himself as a man. For Betty the issue may be one of self-worth being correlated with competence. In the one job her competence stands out, but the conditions are terrible and the rewards are few. Taking the new job holds the potential of proving that her competence was only relative to the incompetent staff surrounding her.

The concept of tolerance of ambiguity (FrenkelBrunswik 1949) is congruent with both the existential view of risk described above and the meaning of risk implied by the theraplsts cited earlier. It also provides further support that decisions involving risk taking are influenced by subjective factors specific to the individual. Tolerance of ambiguity is conceptualized as an aspect of the personality which is capable of accepting conflicting data without a strong need to reconclie the differences immediately. The reverse, Intolerance of ambiguity, is a ". . preference for familiartty, symmetry, definiteness and regularity, - . tending toward black-white solutions [FrenkelBrunswik 1949, p. 112]." These tendencles are considered to be perceptual characteristics found in association with strong attitudes of prejudice and where repression is a dominant defense mechanism. A further characteristic of 
intolefance of ambigulty is the inability to think in terms of probability and the avoldance of uncertainty. An indivflual "intolerant of ambiguity seeks to make fact out of circumstances where fact is unclear so as to reduce the unknown factors. In terms of risk taking, an individual who is intolerant of ambiguity w1ll avold situations where the outcome is not certain or close to 1t. The important point is that the outcome is certain, not necessar1ly whether it is good or bad.

Other research (Martin 1954, Smock 1955a), has suggested that an individual's response to amblguous perceptual situations may result from a specific organization of the personality which structures situations lacking in certainty. Therefore, the individual who percelves the world from such a structuring system w11 act to reduce incoming data to fit the, system rather than have a plece of information that is not, congruent with the structure. Placing data into the system acts to reduce ambiguity. The quality of the outcome may of may not result in objective conclusion, as in the cašle of prejudice.

Hamilton (1957) describes the process in the following way่:

Avoldance of ambiguity as a principle of, and expression of cognitive control is found in association with a relatively high degree of total anxlety, but particularly where the principle defense mechanism adopted by the individual to 
cope with anxiety and conflict is repression. This mechanism leads the individual to deny reality rather than acknowledge it. It becomes generalized to the perceptual field of operation, where by negathye methods of limiting and restricting the ind1vidual's field of awareness and behavior, it tends to lead to the avoldance of responses which might result in uncertainty and anxiety, on account of the degree of perceptual conflict, equivocality and unstructurredness inherent in such situations. By avolaing ambiguity, the Neurotic person, the Conversion Hysteric and Obsessional in particular, would appear to avold both subjective uncertainty and conflictful situations. By avolding uncertainty and conflict, the individual would appear to avold further anxiety [p.215].

What I am proposing is that there are two major factors in decision making involving risk. The first is the overt data, such as odds and potentlal outcomes and rewards that are measurable. The second factor is the potential outcome in terms of existential anxiety and tolerance of ambiguity.

In terms of the overt data, one looks at the situation in a logical and rational manner. "Can I afford to lose ten dollars by betting on a football game when I know my chances are about fifty-fifty?" In response the person might say,

"Yes, I have the money and would not feel any particular

pinch if I lose. I also usually enfoy watching the game more if I have made a bet." The odds are acceptable and the potential loss in terms of money is tolerable.

In the second set of factors one is also logical, but from a different set of assumptions. From the standpoint of 
existential anxiety or tolerance of ambiguity, the question now becomes, "Can I afford to lose ten dollars to that loudmouth in the office who I know will remind me for weeks that I lost the bet?" Given this data the response might be different. For example, "That guy makes me so mad that if I lost the bet I would probably be upset dally by his gloating. Even though the bet is fair and $I$ can afford the money, I cannot afford to have him drive me crazy for the next month if I lose. Therefore I w1II not take the bet unless he will give me some points. Then the odds would be enough in my favor to risk my emotional well-being." The loss, from an existential point of view, is seen in terms of reduction of self-worth resulting from the continual reminders that the bet was lost. The uncertainty of the situation is apparently great enough in terms of the potential loss to decide not to bet. That is, his tolerance of the amblguous factors surrounding the bet is not high enough to accept the wager. How does the above conceptualization of risk which Includes odds, tolerance of ambiguity and both objective and existential loss, fit with existing knowledge on alcoholism and alcoholics? The following section will review the major approaches to alcoholism, and provide a basis for relating risk taking to alcoholism. 


\section{A.lcohollsm}

Since the beginning of recorded history alcohol has been used, and not infrequently abused by a wide variety of cultures. In early socleties alcohol was used for both food and doink; for medicinal purposes, and as a method for reaching a state of religious ecstasy. In modern socleties alcohol is used primarily as a social catalyst and a mood elevator (MacAndrew and Edgerton 1969).

In spite of its continued use, alcohol has been the target of frequent warnings against over-indulgence. Plato observed that alcohol releases in man much that has otherwise been kept dormant. In Rome, Valerius Maximus enforced a strict prohibition against women drinking "lest thereby they fall into some disgrace [McKinlay 1945, p. 14]."

Classical scholar Arthur McKinlay (1945) reports that Pope Clement I warned

- . of the deadly association of wine and women; he criticizes. Women for reveling in luxurious riot, gulping down wine so as to make a show of themselves and hiccuping ostentatiously like men; he advises boys and giris to keep away from wine as an arouser of the passions [pp. 14-15].

In sixteenth century England, Thomas Nash (1592) delinekted more than one sort of drunkenness. "Nor have we one or two kinde of drunkards onely, but eight kindes." He describes the "Ape drunke" who sings "ana hollowes, and daunceth for the heaueris"; the "Lion drunke" who throws pots 
about the house"; the "Swine drunke" who lays "Iumpish and sleeple"; the Sheepe drunke, wise in his owne concelpt when he cannot bring forth a right word"; the fifth is the "MawdIen arunke, a fellowe who will weepe for kindness in the midst of his ale"; the sixth is the "Martin drunke" who drinks himself sober; the next is the "Goat drunke" whose mind turns to lechery; and finally there is the "Fox drunke" who becomes more clever and crafty when drinking (p. 467). An American physician in the early nineteenth century described some of the symptoms of drunkenness in a similar manner:

Certain extravagant acts which indicate a temporary fit of madness. These are singing, halooing; roaring, Imitating the noises of brute animals, Jumping, tearling of clothes, dancing naked, breaking glasses and china, and dashing other articles of household f'urniture upon the ground or floor [Rush 1811, p. 2].

More recently the Ant1-Saloon League described on a poster in 1913 the potential disaster that can befall an individual who drinks:

Alcohol inflames the passions, thus making the temptation to sex sin unusually strong. Alcohol decreases the power of control, thus making the resisting of temptation especialiy difficult. Avold ali alcoholic drink absolutely. The control of sex impulses will then be easy, and disease, dishonor, disgrace and degradation will be avolded.

And finally from $\mathrm{C}$. Nelson Davis, Psychiatrist-inChief of the Malvern Institute for Psychiatric and Alcoholic Studies: "In alcoholism, the equation is simply expressed: 
Man plus alcohol equals psychopathic behavior. Man minus alcohol equals a normally disciplined person [Davis 1962 , p. $17 . "$ "

In the face of the long and energetic history of caution and social disapproval associated with the abuse of alcohol, one cannot help but wonder at the nature of a drug powerful enough to warrant risking the loss of family, work, soclat standing, etc. What then is the nature of alcoholism?

At present individuals who drink more than societal standards dictate are called "alcoholics," "chronic alcoholics," "alcohol addicts," "addictive drinkers," and more recently "problem drinkers." The variety of different terms used to describe the same problem provides some insight into the divergence of theoretical orlentations.

There is no universally accepted definition of alcohollsm, and many scholars contend that the term encompasses a wide range of pathological behavior syndromes associated with alcohol use. "In short, it might be more appropriate to speak of "alcoholisms" rather than alcoholism, since there are a number of distinct disorders whose major characteristic is the pathological seeking for and reaction to, the effects of alcohol [Roebuck and Kessler 1972, p. 3 ].

There is some common ground however. Certain aspects of alcoholism which are common to most theoretical formulations include the following:

1. Self destruction of the alcohol abuser.

2. Interference with the individual's physical, mental and/or social functioning or adjustment. 
3. Exceeding the norms, dietary or social customs of the society in terms of quantity, frequency and time and place of alcohol consumption.

4. Loss of control (1.e., the inablifty to stop drinking) [Roebuck and Kessler 1972, p. 12].

Because of the divergence of theoretical orientations and because it is the most widely held, the World Health Organization (1952) definition will be used:

Alcoholics are those excessive drinkers whose dependence upon alcohol has attained such a degree that it shows a noticeable mental disturbance or an interference with their bodily and mental health, their interpersonal relations, their smooth social and economic functioning; or show the prodromal signs of such development [ $p .5]$.

There are three major theoretical approaches which attempt to describe the etiology and nature of alcoholism. A brief overview of these approaches is necessary to provide an adequate basis for later discussion.

The first general theoretical approach takes as its basic premise that the cause of alcoholism is basically physiofogical. This is the constitutional approach which holds that some physiological or structural defect produces a predisposition which yields addiction when the individual is introduced to alcohol.

Researchers in this area have had some success. For example, the search for a genetic base for alcoholism has produced supportive evidence (Ka1f 1960, Partanan 1966, Ey sencl 1967, McClearn 1959, Rogers 1967), both with human and nonhuman subjects. And there is also some evidence that 
a biochemical defect, which is an inherited metabolic defect, results in nutritional deficiencies (Williams, Pelton and Rogers 1951). Another area of investigation (Tintera 1956) concelves of physlologlcal alcoholism as a symptom of a glandular disorder.

However, the research conducted in support of a constitutional theory has produced nelther consistent nor conclusive results. Lester (1966), for example, has criticlzed many of the constitutional studies on methodological grounds. And McCord, McCord and Gudeman (1960), who conducted the only in-depth longitudinal study on alcoholism using human beings, concluded that nutritional deficlencles, glandular disorders and hereditary factors are not significant factors in the etlology of alcoholism.

The second major theoretical approach is based on the belief that an individual's psychological mechanisms and personality are the major causes of alcoholism. Several orlentations have evolved from this approach. Six of these orlentations will be discussed: alcohol effects, reinforcement or learning theory, psychoanalysis, fleld dependence, alcohollc personality, and transactional analysis.

The "alcohol effects" orlentation is concerned with the ways in which alcohol affects the alcoholic and the reasons stated by the alcoholic for drinking. Evidence from Mulford and Miller (1960) supports the view that alcohol helps the 
alcoholic to feel better about himself and to deal with others in a more constructive way. Kinsey (1966), however, found that alcoholics did not have a better self-concept after drinking, and Tamerin and Mendelson (1969) discovered that after an initial euphoria, Intoxication ylelded feelIngs of guilt, remorse, self-deprecation and protracted crying spells.

Another psychological orlentation toward alcoholism is in terms of reinforcement or learning theory. For these theorists, one develops a drinking problem because of the reinforcing effects of alcohol. For example, in an unfamiliar social setting someone who discovers that alcohol reduces uncomfortable feelings w1ll be more likely to drink alcohol in a similar future situation (Conger 1951; Dollard and Miller 1950).

The psychoanalytic orientation is in terms of passivIty and regression. Fenlchal (1945) clalms that alcoholics use the effects of alcohol ". . to satisfy the archaic oral longing which is a sexual longing, a need for security, and a need for the maintenance of self-esteem simultaneously" (p. 376). Menninger (1963) views alcohol as symbolic of the primal food (mother's milk) and that it works as an artificlal coplng device to relleve stress.

The fleld dependence orlentation (Witkin, Karp and Gooderiough 1959) holds that personal1ty influences percep- 
tion and is therefore understood in terms of modes of perception. A fleld dependent individual reiles on the visual fleld in which the stimuli occur in making judgements about the stimuli. Field dependent people have difficulty in dealing analytically with themselves and their environment; they tend to have difficulty in distinguishing boundaries between self and others and in effect they have a poor sense of separate identity. Karp, et al. (1965) concluded, after a review of literature prior to 1965, that studies generally demonstrated that both male and female alcoholics are markedly fleld-dependent in their perception.

The alcoholic personality orientation contains two contrasting and contradictory points of view (Roebuck and Kessler 1972). One view holds that alcohollsm is a distinct entity and that alcoholics possess a specific personality type which predisposes them to alcoholism. The other view is that alcoholism is a symptom of some other form of psychiatric disturbance.

The final orientation of the psychological approach that will be dealt with in this study is that of Transactional Analysis (Steiner 1969). The transactional orientation is of particular slgnificance in terms of risk taking and will be discussed in detall in the following chapter. The third and final major approach to explaining alcoholism is the soclological approach. This approach is not 
concerned with why a person becomes an alcoholic. Its major alm is directed at explaining and defining rates of alcoholism for different groups. Evidence from this domain has demonstrated that cultural factors play a signiflcant part in determining drinking behavior.

For example, Sadoun, Loll1 and Silverman (1965) in studying drinking patterns in France and Italy, reported that although use of wine is common in both countries, inc1dence of alcoholism is higher in France. France also differed from Italy in terms of quantities of wine consumed between meals, but not during meals, with the French drinkIng more between meals than the Itallans. The Itallans have a lower conception of the "safe IImits" concerning the amount of wine which can be consumed without harm than do the French. The Italians also do not hold with the French bellef that coplous drinking is associated with virility and that intoxication is fashionable.

Snyder (1958) describes the low incldence of alcohol1sm among Jews as function of internal pressure to conform with Jewish norms and customs. Alcohol consumption is learned through ritual drinking which teaches Jews how to drink in a controlled manner.

Cahalan (1970) goes so far as to say that, "Whether a person drinks at all is primarily a soclologlcal and anthropological variable rather than a psychological one 
[pp. 201-202]." He qualified this contention by stating that ". . a person's abuse of a substance is also dependent upon his personality and his Immediate environment [p. 196]." From the above data it should be apparent that an all encompassing explanation for alcoholism is not yet avallable. Because a single model is lacking, an eclectic approach, utilizing aspects from the various theories presented, will be used to relate alcoholism to risk taking. The next chapter will review the literature of both risk taking and alcohollsm as they relate to each other. 


\section{REVIEW OF LITERATURE}

Only two studles were found dealing with risk taking in an alcoholic population. In the first, Rule and Besier (1970) argued that alcoholles have difflculty making dec1sions and that alcohol reduces indecision. To test this hypothesis they administered a hypothetical dilemmas questionnalre to twelve hospitallzed alcoholics and to twelve alcohol counselors. The questionnalre consisted of three 1tems from the Kogan-Wallach Cholce Dilemmas Questionnalre (1964) and two alcohol related dilemmas. The results ind cated that the counselors were wllling to accept lower odds, that is, greater risks, than the alcoholic group. The mean score for the alcoholles was 6.87 on a ten polnt scale with one being very rlsky and ten very conservative, as opposed to a mean score for the counselors of 5.38 . The difference was significant at the $\mathrm{p}<.01$ level.

The authors concluded by suggesting the following process:

It may be that drinking releases the alcoholic from an overly conservative, inhibited stance and moves him towards the other extreme, that of high risk taking. Thus alcohol presumably reduces 
inhlbition. One major need for relief in the nondrinking alcoholic may stem from his conservatism In decision making [Rule and Besler 1970, p. 830].

The second study investigated ethical risk taking in alcoholics. The ethical risks hypothesis postulates that unethical behavior varies as a function of the percelved risk incurred by such conduct (Rettig 1963).

The author (Krause 1971) argued that one reason why an alcoholic drinks is to reduce his fear of fallure. Using the Behavior Prediction Scale (Rett1g 1963) Krause measured the reinforcement value of censure of three groups: hospitallized alcoholics, psychlatric out-patients, and volunteers from The Veterans of Forelgn Wars. The reinforcement value of censure measures how sensitive one is to the magnitude of censure or punishment resulting from getting caught. of the three groups, alcoholics were more sensitive to the reinforcement value of censure than either of the other groups. The results also indicated that alcoholics were more wllling to take ethical risks than were the controls. The authors thus concluded that the alcoholics had a higher fear of fallure than the nonalcoholic and that alcohol acts to reduce that fear, thereby increasing their willingness to take risks.

With reference to risk taking and 1 ts relation to alcohol intake for nonalcoholic subjects, there is somewhat more data. Cohen (1960), for example, discovered that bus- 
drivers were willing to negotiate more difflcult driving courses after they had been drinking than when sober. The task called for the drivers to maneuver a bus through a series of poles a standard distance apart before and after ingesting alcohol. In both drinking and sober trials drivers were required to state their subjective judgement as to the level of risk involved. After drinking, the drivers were wllling to drlve the bus through poles that were significantly narrower. Interestingly, the drivers stated that the subjective level of risk was the same under both sober and drinking conditions. Alcohol appeared to have modifled the drivers' perception of the risk involved, making the drivers more wllling to take objectively defined risks. Teger, Katkin and Pruitt (1969) in a gambling experiment concluded that subjects were more risky after drinking than when sober. They surmised that alcohol reduces fear of fallure and subsequentIy increases willingness to risk. Ehlers (1966) found that subjects took greater risks under the influence of alcohol but only when the conditions of the risk were familiar. When the situation was unfamiliar the alcohol subjects were more cautious than the sober subjects. Hurst (1969) in another gambling experiment determined that drinking subjects were more willing to make larger bets when their personal estimate of the odds, their subjective probability, was high, than when the subjective probability was 
low. Under the low subjective probablilty condition the subjects showed elther no change in betting behavior or became more caut1ous.

It would seem that fear of fallure thus plays a significant role in alcohol consumption for alcoholics. The results of Krause (1971) and Rule and Besier (1970) would support a view that alcohol acts to reduce fear of fallure and may thereby make decision making and other action where fallure is an issue, less anxiety ridden.

Studies measuring risk taking under conditions of alcohol influence with nonalcoholic subjects have also demonstrated that the ingestion of alcohol reduces fear of fallure and increases willingness to take risks (Cohen 1960; Teger, Katkin and Pruitt 1969). The Hurst (1969) and Ehlers (1966) studies, however, indicate that there may be specific situations where alcohol does not increase wlllingness to risk.

There are two directions avallable at this point given the absence of a significant amount of data relating alcohollsm or alcohol and risk taking. One might be to discuss the theoretical and experimental evidence on alcoholism and Ident1fy some implications for general risk-taking behavior of alcoholics. A second alternative might be to relate some of the generally accepted characteristics of alcoholics to 
experimentally derived data about risk taking. I shall deal with both and start with the former.

Some models of alcoholism deal quite directly with the concepts of risk and ambigulty. The Transactional Analysis model (Berne 1967, Stelner 1971) provides a basis for understanding alcohollsm in terms of risk taking because of its concept of childhood decisions.

This theory postulates that from the moment a child is born he begins recelving data about what the world is like. In addition to the observational data the child recelves from his environment he also recelves from his parents inJunctions on how he is to behave and also verbal data about "Iife" and how to function in the world. Based on this data the child makes decisions on how he is going. to live up to his parents' requirements and st1ll malntain his personal autonomy. For the alcoholic the early declsion is that he is "not $O K$ " but that the rest of the world is all right. The conflict for the child is that while he is not treated in a way which allows him to feel good about himself, he also sees that his parents are not living the kind of life they are demanding of him. Therefore the complete early decision is that "I'm not $\mathrm{OK}$ and you are, ha, ha." The laugh signifles that underneath the admission of guilt is the belief that those people who are admonishing him for his bad conduct are just as guilty as he. 
The remainder of the alcoholic's life is structured around creating situations which validate these early life decisions. The method for accomplishing this feat is the "Alcoholic Game" (Stelner 1971). Risk for the alcoholic from a transactional point of view is to act in conflict with the early life decision. Much as Maslow (1968) and Polster (1972) have indicated in terms of their therapies, the individual thus prefers to remain in the security of the known rather than risk the ambiguity and/or uncertainty of the unknown. In Transactional theory, security is to play the "Alcohollc Game" and thereby maintain the early, childlike view of the world.

It seems reasonable to assume that those individuals who are unwilling or unable to tolerate a moderate amount of amblguity or to take a reasonable risk would be the ones most likely to keep drinking as the best way to continue playlng the game. Thus, one conclusion that might be drawn from the 11terature on Transactional Analysis is that those alcoholics who demonstrate the greatest tolerance of amb1guity and demonstrate the greatest willingness to take moderate risks would be the ones having the best prognosis.

It is important to note at this point that risk and ambiguity in a Transactional Analysis context refer to the same thing: a capacity to withstand the pressures of the unknown. Taking risks which virtually assure fallure, low 
odds of success, although risky in terms of odds are often the precursors of the next drinking episode.

Another theorist (Bateson 1971) argues that sobriety for the alcoholic is itself the pathological state and that drinking provides some correction for this error. "In other words, compared with his sobriety, which is in someway 'wrong' his intoxication must be in someway 'right' [p.2]." The basis for this logic is the epistemological position that conscious will, or "self" is separate and distinct from the remainder of the personality. What the alcoholic does is to deny the unpleasant actions he takes in order to say: "That wasn't I who did that, it was the alcohol," or, "I don't know what came over me." In each instance the alcohollc separates his sense of "self" from behavior that is incongruous with his idealized notion of himself. Basic to this separation, is the belief that consclous will is the "self" and to be in tune with that will is to be all right. Bateson uses the idea of "alcoholic pride" to illustrate his point. Pride for the alcoholic is not contextually structured around past achlevements. Instead it is structured around a response to the challenge of "I can quit" or, "I can stay sober." The emphasis is in the challenge with success being less important than the act of achleving success. After a perlod of success the challenge diminishes and the new challenge becomes, "I can take a 
drink and not go on a binge." It is now no longer good enough to say, "I have quit." Thus the challenge component of "alcoholic pride" is linked to risk taking with the principle being, "I can do something where success is $1 \mathrm{~m}-$ probable and fallure would be disastrous [Bateson 1971, p. 9]."

It seems that for an alcoholic there are two acceptable states. One is the drunken condition which is vold of any responsibility for elther self or others. The second state is to be sober, but sober in a way which makes the alcoholic appear superhuman--someone who can, at will, return to drinking at an acceptable level.

The challenge component of pride is further reduced from the stated test of self-control, "I can take a drink and stop," to the unstated and unstateable purpose of provIng that self-control is ineffectual and absurd. The proposition that self-control will not work is a policy decision formed ". . In the levels of the mind [which] are prelinguistic and the computations which go on there are coded in primary process [Bateson 1971, p. 121." The risk of taking a drink to prove that it can is in reality a "set-up" which w111 prove that it cannot be done and that therefore self-control is not attainable.

Both articles would agree that risk for the alcoholic need be defined from the alcoholic's point of view. 
Therefore, in measuring risk taking in an alcohollc, one need be aware that odds and probabilities are not the sole basis on which to judge whether the person is risking or not. For most people, the act of taking a drink by an alcoholic may seem a tremendous risk in terms of the potential for him to return to uncontrolled drinking. For the alcoholic the act of taking a drink may be the best way to continue playing the "Alcoholic Game" and prove that selfcontrol is absurd.

By looking at both the data on alcoholism and the data on risk taking several overlapping areas can be found. Both Krause (1971) and Rule and Besier (1970) referred to "fear of fallure" as a motivating force in the behavior of alcoholics. "Fear of fallure" may also be construed as a motivator in general risk taking behavior.

McClelland, Atkinson, Clark and Lowell (1953) developed a theory of achievement motivation that incorporates the concept of fear of fallure and risk taking. The model postulates that there are two kinds of motives for situations in which one is attempting to meet a criterion of excellence: the motive to achleve success and the motive to avold fallure. All people are supposed to have each of these motives, but in varying degrees. These two motives, when combined with an Individual's subjective probabilities and incentives, yleld a measure of risk-taking behavior. 
Expressed algebralcally these are:

Motivation $=\left(M_{S} \times P_{S} \times I_{S}\right)+\left(M_{f} \times P_{f} \times I_{f}\right)$.

$M_{S}=$ Motivation to achieve success.

$P_{S}=$ Subjective probability of success.

$\dot{I}_{s}=$ Incentive value of success.

$M_{f} P_{f} I_{f}$ are the motivation, probability and incentive values associated with avolding fallure.

When motivation to achieve success is stronger than motivation to avoid fallure, the total motivation factor is strongest when the probability values are at .5. The following example should lilustrate this point:

$$
\begin{aligned}
& \left(M_{S} \times P_{S} \times I_{S}=\text { Approach }\right)+\left(M_{f} \times P_{f} \times I_{f}+\text { Avoidance }\right)=\text { Resultant } \\
& \begin{array}{lllllllll}
2 & 0.1 & 0.9=0.18 & 1 & 0.9 & -0.1= & -0.09 & 0.09
\end{array} \\
& \begin{array}{lllllll}
2 & 0.5 & 0.5=0.50 & 1 & 0.5 & -0.5=-0.25 & 0.25
\end{array} \\
& \begin{array}{llllllll}
2 & 0.9 & 0.1=0.18 & 1 & 0.1 & -0.9= & -0.09 & 0.09
\end{array}
\end{aligned}
$$

Therefore, individuals in whom the motivation to achieve success is stronger than the motivation to avold failure should be drawn to situations of intermediate difficulty, those possessed of moderate odds. Those individuals with stronger motivation to avold fallure wili choose situations where the odds are either very high or very low. A conservative response, high odds of success, is consistent with the individual's need to avold fallure. The risky low odds of success response is also a way of dealing with fear of 
fallure because with very low odds, success is generally not anticipated by those evaluating one's performance.

Studies by Atkinson, Bastion, Earl and Litwin (1960) and Atkinson and Litwin (1960) were supportive of the achlevement motivation model. However, since those experiments, Littig (1963) and Raynor (1966) have posed questions as to the generalizability of the construct in different situations. Under experimental conditions where competition is an issue, fear of fallure subjects preferred high risk cholces over extreme conservatism. Also under competitive conditions, high need achlevers demonstrated an increasing preference for conservative bets as the experiment went on. In general, however, the model still seems valid for noncompetitive situations and therefore useful in terms of the present study.

Given that "fear of fallure" is a motivating force for alcoholics, one might hypothesize a preference for extreme conservatism or risk as being likely. One could further hypothesize that a reduction in this preference for extreme odds would be indicative of a reduction in "fear of failure" and therefore a reduction in the motivation to drink.

Studies on fleld dependence (W1tkin, Karp and Goodenough 1953; Karp, W1tkin and Goodenough 1959) have demonstrated that alcoholics are more fleld dependent than are nonalcoholics; that 1s, very dependent on the visual 
fleld in which the stimuli occurs in terms of making judgements about the stimuli. Another group of studies (Wertheim and Mednick 1958; Meyer, Walker and Litwin 1961) have demonstrated that field dependence is positively correlated with high fear of fallure. High fleld dependence and high fear of fallure go together. From this line of reasoning we arrive at the conclusion that alcoholics will be more likely to advocate odds either risky or conservative as opposed to moderate odds.

Yet another way of relating the work on fleld dependence and alcoholism is to examine the definition. Field dependent people seek structure from the environment and view the environment as controlling them as opposed to their controlling the environment. Risk-taking data (Rotter 1962) regarding individuals who see the locus of control as being external show that these people preferred odds which were elther risky or conservative. Those seeing the world as something which can be controlled preferred moderate risks. Kogan and wallach (1967) conducted experiments seeking to determine whether risk-taking strategles were generalized throughout a series of different contexts. In each context the subject chooses a risk-taking strategy and must stay with that strategy for a flxed period of time. At some point the experimenter offers the option of changing. strategies. Persons with high motivational disturbances, as measured 
by test anxiety and defensiveness scores, exhibited substantial degrees of constancy in their risky or conservative strategles. Those with low motivational disturbance scores showed more variability in strategies between the different tasks. They seemed to see more options and were willing to use them. When offered an opportunity to change strategies those who scored low on the motivational disturbance scales took advantage of the opportunity if they were losing. That 18, their risk-taking strategy was not working. Those who scored high on the motivational disturbance scales and were losing, did not express a desire to change their strategles. on the contrary, they seemed satisfied with their bets. Kogan and Wallach (1964) concluded:

- . not only does the risky conservative behavior of maximally disturbed individuals seem strongly generalized in the sense of showing high consistency across varying tasks and situational contexts, but this behavior also tends to lead the individual into maladaptive postures toward his environment [p. 203].

on the basis of this data one might expect that alcoholles who show little change in their risk taking strategles would continue to behave in the same "maladaptive" manner as before and therefore continue to drink.

In summary, the author feels the data on risk taking and alcoholism appear to warrant the following conclusions:

1. Reduction of "fear of fallure" is a motivating force for the nondrinking alcoholic and the ingestion of alcohol seems to reduce this fear. 
2. Scores for alcoholics on risk-taking instruments w11l show a preference for odds of extreme risk and/or conservatism as a positive function of "fear of fallure." That is, as "fear of fallure" decreases, preference for extreme odds will reduce.

3. "Risk" for alcoholics should be measured in terms of tolerance of ambiguity or moderate odds and not for extreme risk taking. 


\section{CHAPTER III}

\section{METHODS}

\section{Procedure}

Sixty hospltalized alcoholics were given the KoganWallach Cholce Dilemmas Questionnalre (Kogan and Wallach 1964) upon admission to the Dammash State Hosp1tal Alcohol Treatment Program. Criteria for subject selection was: to have voluntarily agreed to participate in the research, and to have been admitted to the Alcohol Treatment Program no longer than four days prior to completion of the testing. No further requirements were made of the subjects unt1l four days prior to discharge from the Alcohol Treatment Program. Within that four day period each subject was again given the Kogan-Wallach Cholce Dilemmas Questionnaire. Since only one form of the questionnaire was used, each subject therefore responded to the same 1tems twice; once on admission and once on discharge.

Procedure for administering the questionnaire was as follows: each subject was seen Individually. The subject was asked to read the instructions, after which any questIons he had were answered. When the subject had stated he understood the requirements of the task he was then asked 
to explain in his own words what he was supposed to do. Any errors in his understanding of the task were corrected before allowting the subject to complete the questionnaire. Subjects who could not grasp the requirements of the questionnaire, in the experimenter's judgment, were excluded from the sample. The questionnalre was then completed in the presence of the experimenter.

Administration of the questionnaire at the time of discharge differed from the initial procedure in the followIng ways: I) Subjects were again required to paraphrase the task of the questionna1re, to the satisfaction of the experimenter, but this time they were not required to reread the instructions. 2) Subjects were not required to complete the questionnalre in the presence of the experimenter because of the frequent conflict between Program requirements and experimenter availability. Subjects completed the questionnalre at their convenience and returned it before leaving the hospital. 3) Subjects were not told why they were taking the questionnalre the second time until just prior to discharge and only at their request.

All subjects were told that particlpation in the research was voluntary and that all responses would be held in strict confidence. The questionnalre was described as a device for measuring attitudes and opinions and it was emphasized that there were no right or wrong answers. 
Additionally, the subjects were told that the research was being conducted as part of the author's education and that any direct benefit to them was Ilkely to be small. The purpose of the research was explained as an attempt to measure how individuals with drinking problems viewed different sorts of decision-making dilemmas.

Data concerning attendance at the out-patient clinics was collected by Alcohol Treatment Program staff as part of their own record keeping. The experimenter used the Program records to obtain out-patient attendance data pertinent to this research.

In this manner three sets of primary data were obtalned. The first consisted of questionnalre response durlng the early stages of the treatment program. The second consisted of questionnalre responses just prior to discharge or after the treatment program was virtually completed. The final data was the frequency of attendance at the outpatient clinics after the subject was discharged from the hospltal. For subjects to be consldered attending an outpatient clinic, they had to come to the clinic four times during the three month follow-up period.

\section{Risk-Taking. Instrument}

The Kogan-Wallach Choice Dilemmas Questionnaire (CDQ) (Kogan and Wallach 1964) conslsts of twelve situations, each 
contalning a central person faced with a choice between two courses of action. One of these courses entails a greater risk of fallure, but also ylelds greater rewards if successful. The second course of action is to choose a safe, stable, non risky, but less rewarding alternative. The subject's task is to advise the person in each of the twelve situations by selecting the probability of success considered sufficlent to warrant choosing the risky alternative.

The author feels there are several drawbacks to using this questionnalre as a measure of risk taking. The most obvious is that subjects are not required to risk anything. The measure is hypothetical. Another potential difficulty Involves the complexity of the task, in terms of the subject's capacity to understand and provide valid answers. A third problem area involves the content of the items, in that the sltuations may not tap the real world of the alcoholic and they are exclusively male orlented.

The flrst drawback is, in part, a specific case of the generalized question of whether or not one can take data gathered in a laboratory and extrapolate to the real world. More specifically, the question is whether one can general1ze from a hypothetical measure of risk taking to a real, albelt laboratory, measure and then from the laboratory to the real world. Evidence to date (Myers and Sadler 1960; 
Katz 1962; and Suydam and Meyers 1962) suggests than an Individual's strategy or attitude toward risk taking remains generally constant over the two conditions, but may shift slightly toward conservatism in the real risk-taking situations.

The second area of concern--the capacity of the subjects to provide valid responses--was controlled via the administration procedures outlined earlier in this chapter.

The third problem area, that of the content of the dilemmas, could have been reduced by developing a questionnalre that would include alcohol dilemmas appropriate for both men and women. The pragmatic factor of time involved in developing such a questionnaire precluded this as an alternative.

There were many advantages to using the $C D Q$. The first, was that the questionnalre had been used in a variety of other risk-taking experiments and thus provided a base for discussion of data from the present study to others. A second advantage to using the $C D Q$ was the capacity of the questionnalre to provide data on both odds and ambigulty. The third advantage also deals with the content of the 1tems. Although the items may not tap the real world of the alcoholic, both male and female, they do attempt to present a serles of problems which are closer to reality than many of the other measures of rlsk taking. The typical measure 
of risk taking (other than the CDQ) involves participation in some sort of game-11ke situation.

\section{The Therapy Program}

The Dammasch State Hospital Alcohol Program is funded by a Federal grant and has a staff that consists of two physlclans, two soclal workers, six casemanagers, one clinical psychologist, five registered nurses and twenty psychiatric aldes. The simplest way to describe the operation of the program is to outline the process by which an individual is admitted, treated and followed after discharge.

Males are admitted to the general psychiatric wards for detoxification. Women are admitted to the ward on which the program takes place, but are not involved in the program until after they have been detoxified. The length of the detoxification process varies, but it usually takes five days. During this time period the individual is contacted and informed of the nature and content of the Alcohol Treatment Program, and the alternatives avallable throughout the hospitai. Should the patient request admission to the program he is given the MMPI and an appointment for screening. Admission to the program is not automatic. The screening process includes an evaluation of the patient's motives, needs and desires and the capacity of the hospital program to ineet them. At the screening meeting a treatment 
contract is worked out and, if admitted, the patient is transferred to the program ward the same day. The contract for treatment includes a stated desire to change or modify some aspect of their personality that is workable in the hospital setting. The contract also indicates the patient's agreement to participate in the program and an agreement to stay in the program for the required length of the therapy, thirty days.

Individuals not admitted to the program will typically state that they have no desire to quit drinking and they are only in the hospital to recover their physical strength; or that they are only interested in getting off the wards where all the "crazy" people are; or that they do not feel any need for change in their behavior except to stop drinking. Approximately 80-90 per cent of those requesting admission are, in fact, admitted.

The program itself is centered around particlpation in a wide variety of group therapy experiences. Many of the groups are orlented to provide an atmosphere where an individual can discuss his or her problems and recelve feedback from the therapist and/or other group members. The remainder of the groups have speciflc topic areas or techniques, but at the core of all groups is the goal of expression of feellings. 
The names of groups and their agendas are listed below:

Alcohol Orientation Class - This meeting is held three times each week for one hour. All patients are expected to attend. The meeting consists of a series of lectures on alcohol and alcoholism.

A.A. - Alcohollc Anonymous meetings are held in the hospital twice each week and all patients are encouraged to attend.

Assertiveness Training - This group is designed to look at feelings around subassertive behavior and to provide techniques and opportunities to practice assertive behavior.

Logotherapy - Logotherapy is essentially a group where individuals look at the goals in their lives and evaluate whether they are going about achieving these goals in an efficient or productive manner.

Women's Group - The women's group is devoted to looking at the problems of women in our soclety and specifically women with arinking problems.

Couple's Group - Marital or relationship counseling is emphasized here. Particular attention is paid to communication skilis.

Recovery, Inc. - This organization is similar in goals and structure to A.A., but includes individuals with problems of a strictly emotional nature in addition to alcohol related problems.

Relaxation Therapy - This group teaches relaxation techniques.

Relationship Improvement - Emphasis is placed on discovering the ways in which individuals under-. mine their relationships with others and provides an arena for practicing new techniques.

Iooking Inside - Increasing one's self-awareness is the goal. 
Transactional Analysis - This group looks at the problems of alcohollsm from the perspective of the alcoholic game.

Attendance as Change

The use of attendance at the out-patient clinics as a criteria for change was chosen for three reasons. First, it was the clinical opinion of the Alcohol Program staff based on experience that patients who do not attend follow-up counseling show a higher rate of recidivism than those who become involved in the out-patient clinics. Gerard and Saenger (1966) also found this to be true. The following is an excerpt from their study on "Out-Patient Treatment of Alcoholics" :

Extent of treatment was associated with improvement in drinking. (The reader is reminded that the patients were classified in three groups with respect to extent of contact: minimal (one to four visits), moderate (five to ten visits), and persistent (eleven to more than twenty visits). Only 11 per cent of the group who had minimal contact with the clinics improved in drinking, compared to 15 per cent of those who had moderate contact, and 21.4 per cent of those with persistent contact. Extent of contact with the clinics was also assoclated with prolonged abstinence at any time during the year between intake and follow-up; and with improvement as measured by the index of change in over-all adjustment. For example, patients who changed at least moderately in over-all adjustment (that is, dropped an average of at least one point from each of the five component indices), were found far more often among those who had persistent or moderate contact with the clinics than among those with minimal contact $(x=37 ; p=.001)[\mathrm{pp} \cdot 134-36]$. 
They concluded by stating that extent of contact at the outpatient clinics was directly related to improvement in drinking and secondarily related to improvement in the other aspects of functioning.

A second reason for using out-patient attendance was that the very act of going to the out-patient cilnic may in itself be a measure of willingness to risk. The Federal Grant Proposal was based on the bellef, supported by the patients, that a major reason for not attending out-patient clinics was that they were unsure of what to expect or how they were going to be treated. Sapir (1958) in her article about out-patient clinics for the treatment of alcoholism states that one of the functions of the intake interview is to ". . . reduce the new patient's fear of what he has let himself in for by coming to the clinic [p. 129]."

A third and very critical reason for using attendance at out-patient clinics as the improvement criterion was one of methodological pragmatism. That is, given the resources avallable to the author a comprehensive follow-up study looking at the multiple aspects of a patient's functioning after discharge was not possible.

\section{Analysis}

Because risk for alcoholics cannot be measured strictly in terms of odds, two additional measures will be 
used: ambigulty and preference for extreme odds or sure bets. These measures are operationally defined in the following section.

The data will be analyzed in two ways. First, in terms of changes between pre-program testing (PrPT) and post-program testing (POPT) as a function of the variables; sex, age, days in program, and MMPI scale scores for anxlety and defensiveness. The last three variables require further definition.

For age, PrPT and PoPT scores will be divided into three age groups: thirty and under, $\mathrm{N}=17 ; 31-50$ years, $\mathrm{N}=26$; and 51 years and over, $\mathrm{N}=17$. Scores w1ll be analyzed in terms of changes within each group and differences between groups for both testing conditions.

For anxiety and defensiveness, subjects will be divided into two groups using a median split with the two scales. Defensiveness and anxiety scales were taken from An MMPI Handbook (Dahlstrom and Welsh 1960). The resulting groups will be High Defensiveness/High Anxiety (HD/HA), and Low Defensiveness/Low Anxiety (LD/LA). Scores w11l be analyzed in terms of changes within groups and differences between groups.

For days in the program, again PrPT and PoPT scores are divided into three groups composed of subjects who remalned in the program less than twenty-one days, subjects 
who stayed twenty-two to twenty-elght days and subjects who remained twenty-nine days or more. Scores will be analyzed in terms of differences between groups and changes within groups.

The second method of analysis will be to divide the entire sample into two groups composed of subjects who attended the out-patient clinics after discharge and subjects who did not. The groups will be called the follow-up group (FU) and the non follow-up group (NFU). Data will be analyzed in terms of differences in PrPT and POPT, change scores and the varlables of age, sex, days, and defensiveness and anxiety.

\section{Operational Definitions}

Odds. Odds will be operationally defined in this study as the sum of the lowest acceptable probabilities advocated by the subject. Therefore, given twelve 1tems, the most conservative score would be 120 . That would require the subject to check the response, "No" for each item, meanIng that under no clrcumstances should the hero of the dilemmas risk his present position. The most risky score would be twelve, which would mean that the subject was willIng to recommend probabilities of one in ten for each 1tem. The sum of twelve 1tems with a "No" response is ten, twelve times. The sum of twelve items with a one in ten response is one, twelve times. 
Example: Subject $X$ advocated the following probabilities for each item:

$\begin{array}{ll}\text { 1. } 3 \text { in } 10 & \text { 7. } 5 \text { in } 10 \\ \text { 2. } 7 \text { in } 10 & \text { 8. } 9 \text { in } 10 \\ \text { 3. } 5 \text { in } 10 & 9 . \text { No }(\text { or } 10 \text { in 10) } \\ \text { 4. } 1 \text { in } 10 & \text { 10. } 3 \text { in } 10 \\ \text { 5. } 9 \text { in } 10 & \text { 11. } 7 \text { in } 10 \\ 6.3 \text { in } 10 & \text { 12. } 9 \text { in } 10\end{array}$

The sum of the first number in the probability statements is the odds score. For the example stated above the score would be seventy-one.

Ambiguity. The ambigulty score is derived from the odds score. It is assumed that the odds, five in ten, is the cholce with the greatest ambiguity. The rationale is that those odds offer the least information as to the potential outcome. One has equal chances of elther success or fallure. Scores of three in ten and seven in ten are equally ambiguous because one is 70 per cent sure of the outcome. In the case of the risky cholce, three in ten, one can be fairly sure that the outcome will result in failure. In the case of the conservative cholce, seven in ten, again one can be 70 per cent sure that the outcome w11l result in success. In terms of tolerance for amblguity it is not important whether the outcome is success or fallure, but just that the outcome is predictable. The same line of rea- 
soning holds for one in ten and nine in ten, at a 90 per cent assurance of the outcome. When the individual chooses the "No" response he is saying, "I am not willing to risk anything," and this represents the least tolerance for amb1guity. Amblguity scores are calculated by assigning a score of one to the probabilities cholce of five in ten; three to the probabilities cholces of both three in ten and seven in ten; five to the probabilities cholces of both one in ten and nine in ten; and six to the "No" response.

Example: Transformation of Odds score into Ambiguity score:

$\begin{array}{rlllll}\text { Item } 1.3 \text { in } 10 & 3 & \text { Item } 7.5 \text { in } 10 & 1 \\ 2.7 \text { in } 10 & 3 & 8.9 \text { in } 10 & 5 \\ 3 . & 5 \text { in } 10 & 1 & 9 . & \text { NO" } & 6 \\ 4 . & 1 \text { in } 10 & 5 & 10.3 \text { in } 10 & 3 \\ 5 . & 3 \text { in } 10 & 3 & 11.7 \text { in } 10 & 3 \\ 6.9 & \text { in } 10 & 5 & 12.9 \text { in } 10 & 5\end{array}$

The Amblgulty score for this group of probability choices is forty-three.

Sure Bets. These are the responses which consist of the odds, one in ten, nine in ten, and "No." Cholce of one of these three probabilities is indicative of a desire to have maximal certainty. Sure Bets will be scored in terms of frequency of cholce of one of these probabilities in each 
questionnaire. A Sure Bet score of five on a questionnalre would Indicate that on five of the twelve items the subject advocated one of the sure bet probabilities.

Increased Risk Taking. This phrase will be used in many of the hypotheses. In each case it will mean a decrease in the scores for odds, ambiguity and preference for sure bets. A decrease in the odds score reflects a willingness to accept fewer chances of success, or increased riskyness. A decrease in ambiguity scores is indicative of increased tolerance of ambiguity. A decrease in preference for sure bets reflects that the subject is advocating fewer sure bets. All decreases are determined between pre-program testing and post-program testing.

Alcoholics. It is assumed that individuals requiring hospitalization for their drinking problems meet the requirements outlined in the World Health Organization definition. Therefore, "Alcoholics" is defined as those individuals admitted to Dammasch State Hospital with a diagnosis of alcohol addiction.

Hypotheses

Hypothesis \#1. The follow-up group (FU) w1ll show larger changes between pre-program testing (PrPT) and postprogram testing (POPT), in the direction of increased risk taking, than the non follow-up group (NFU) for odds, ambiguity, and preference for sure bets. 
Hypothesis \#2. The FU group scores for odds, amb1guity and preference for sure bets w1ll be lawer numerically in the POPT condition than the NFU group.

Hypothes1s \#3. Subjects categorized in terms of high defensiveness and high anxiety will show less change in risk scores for odds, ambiguity and preference for sure bets than those subjects categorized as low defensiveness and low anxlety .

Hypothesis \#4. Differences between PrPT and PoPT for odds, ambigulty and preference for sure bets will be greatest with younger subjects in the direction of increased $r$ isk taking and differences will decrease with increased age.

Hypothesis \#5. Risk scores for the age group thirty years and under will be less than scores for age group thirty-one to fifty years which will be less than scores for fifty-one years and over.

Hypothesis \#6. Differences between PrPT and PoPT scores for odds, ambiguity and preference for sure bets will increase as a function of increased number of days spent participating in the program.

Hypothesis \#7. There will be no significant differences between men and women for odds, ambiguity, or preference for sure bets in either the pre or post-program testing scores. 
Hypothes1s \#8. There will be no significant differences between men and women for odds, ambiguity and preference for sure bets in terms of amount of change between PrPT and PoPT.

Definition of Symbols

$A_{1}$ - Pre-test sum of lowest acceptable probabil1ties.

$A_{2}$ - Post-test sum of lowest acceptable probabilities.

$B_{1}$ - Pre-test sum of ambiguity scores.

$\mathrm{B}_{2}$ - Post-test sum of ambigulty scores.

$c_{1}$ - Frequency of scores falling in the set defined by items numbers 1,9 , or No, in pre-program condition. (PSB)

$\mathrm{C}_{2}$ - Frequency of scores falling in the set defined by 1tems numbers 1,9 , or No, in post-program condition.

PrPT - Pre-program testing.

PoPT - Post-program testing.

FU - Follow-up group. Subjects attending outpatient clinics.

NFU - Non follow-up group. Subjects not attending out-patient clinics. 
CHAPTER IV

\section{RESULTS AND DISCUSSION}

The chapter w1ll be organlzed into three sections. The first section will present the results and analysis of data speciflcally related to the hypotheses. The second section w1ll present findings relating the secondary var1ables (age, sex, etc.,) to attendance at the out-patient clinics. The third section will discuss all of the results and suggest possible interpretations.

Section 1

Hypothesis \#1. The follow-up group (FU) will show larger changes between pre-program testing (PrPT) and postprogram testing ( $P \circ P T$ ) in the direction of increased risk takingl than the non follow-up group (NFU) for odds, amb1gu1ty, and preference for sure bets.

The mean scores for odds, ambigulty and preference for sure bets in the pre-program (PrPT) and post-program (PoPT) testing conditions for the follow-up group (FU) are presented in Table I.

${ }^{1}$ Note that on page 50, "Increased risk taking" is defined in terms of decreases in scores for odds, ambigulty, and preference for sure bets. See definition for further explanation. 
TABLE I

MEAN RISK SCORES FOR FOLLOW-UP GROUP

\begin{tabular}{lccc}
\hline & Odds & Ambiguity & $\begin{array}{c}\text { Preference For } \\
\text { Sure Bets }\end{array}$ \\
\hline PrPT & 75.61 & 44.22 & 5.65 \\
PoPT & 66.42 & 38.70 & 4.04 \\
\hline
\end{tabular}

All scores changed in the direction of increased risk taking. The $t$ test for related measures (Bruning and Kintz 1968) was utilized to evaluate differences between the two testing conditions. The .05 probability level of significance for a one talled test was used. Differences are statistically significant for all three measures: odds, $t=3.052, d f=22, p<.01$; ambiguity, $t=4.198, d f=22$, $p<.001$; preference for sure bets, $t=4.021, d f=22$, $\mathrm{p}<.001$.

Mean scores for odds, ambiguity and preference for sure bets in the pre and post-program testing conditions for the non follow-up group (NFU) were not significantly different at the .05 level. (Table II). 
TABLE II

MEAN RISK SCORES FOR NON FOLIOW-UP GROUP

\begin{tabular}{lccc}
\hline & Odds & Ambiguity & $\begin{array}{c}\text { Preference For } \\
\text { Sure Bets }\end{array}$ \\
\hline PrPT & 68.75 & 41.69 & 4.47 \\
PoPT & 66.78 & 39.86 & 4.33 \\
\hline
\end{tabular}

One way that the FU and NFU groups seem to differ is in terms of change in risk-taking attitudes. The FU group risk scores changed in the direction of increased risk takIng to a significant degree whereas the NFU group risk scores did not. To further evaluate the differences between the two groups in terms of changes in risk scores the mean change for odds, ambigulty and preference for sure bets was compared. The mean change was calculated by averaging the differences between PrPT and POPT scores for each risk measure. In Table III, 9.19 represents the average change for the odds score between PrPT and PoPT for the follow-up group. For the non follow-up group the average change was 1.97. The differences in the mean change for all risk measures were tested for signiflcance using the t test for Independent means (Bruning and Kintz 1968). The .05 probability level of significance for a one tailed test was 
used. The FU and NFU mean change were significantly different for all measures with the FU mean change being larger In each case: odds, $t=1.923, \mathrm{~d} f=57, \mathrm{p}<.03$; amblguity, $t=1.93$, df $=57, p<.03$, preference for sure bets, $t=2.50$, df $=57, p<.01$.

TABLE III

MEAN CHANGE SCORES FOR RISK MEASURES

IN FU AND NFU GROUPS

\begin{tabular}{lccc}
\hline & Odds & Ambiguity & $\begin{array}{c}\text { Preference For } \\
\text { Sure Bets }\end{array}$ \\
\hline \multirow{2}{*}{ FU } & 9.19 & 5.21 & 1.61 \\
NFU & 1.97 & 1.83 & .14 \\
DIFFERENCE & 7.22 & 3.69 & 1.47 \\
\hline
\end{tabular}

Based on the above data, Hypothesis \#I is accepted. The follow-up group changed significantly in the direction of increased risk taking whereas the non follow-up group did not and the amount of change was significantly larger for the follow-up group.

Hypothes1s \#2. The FU group scores for odds, amb1guity and preference for sure bets will be lower numerically in the PoPr condition than the NFU group. 
Table IV presents the PoPT means for odds, ambiguity and preference for sure bets for the FU and NFU groups. The differences are barely in the predicted direction. That is, the FU group scores are only slightly less than the NFU group scores and the differences are insignificant. Therefore Hypothesis \#2 is not accepted.

TABLE IV

POST-PROGRAM RISK MEANS FOR

FU AND NFU GROUPS

\begin{tabular}{lccc}
\hline & Odds & Ambiguity & $\begin{array}{c}\text { Preference For } \\
\text { Sure Bets }\end{array}$ \\
\hline FU & 66.42 & 38.70 & 4.04 \\
NFU & 66.78 & 39.86 & 4.33 \\
\hline
\end{tabular}

Hypothesis \#3. Subjects categorized in terms of high defensiveness and high anxiety will show less change in risk scores for odds, ambigulty and preference for sure bets than those subjects categorized as low defensiveness and low anxiety.

Table $\mathrm{V}$ presents the mean amount of change of subjects in the high defensiveness/anxiety and low defensiveness/ anxiety categories for odds, ambiguity and preference for sure bets. 
TABLE V

CHANGE SCORES FOR RISK MEASURES

IN MMPI CATEGORIES

\begin{tabular}{lccc}
\hline & Odds & Amb1guity & $\begin{array}{c}\text { Preference For } \\
\text { Sure Bets }\end{array}$ \\
\hline $\begin{array}{l}\text { High Defensiveness/ } \\
\text { Anxiety } \\
\text { Low Defensiveness/ } \\
\text { Anxiety }\end{array}$ & 16.38 & 6.25 & .25 \\
\hline
\end{tabular}

In the low defensiveness/anxiety category the differences between PrPT and PoPT for each risk measure are insignificant at the .05 level. In the high defensiveness/anxiety category the differences between PrPT and PoPT are signiflcant for odds $(t=2.074, d f=7, p<.05)$ for a one tailed test for related measures. There are no significant differences for ambigulty or preference for sure bets.

The odds measure was the only measure where there was a significant difference between the two groups, high defensiveness/anxiety and low defensiveness/anxiety, in terms of mean change score $(t=1.98$, df $=22, p<.05)$. There were no significant differences in terms of mean change scores for the other two measures, ambiguity and preference for sure bets. 
With the only significant differences being in the category not predicted by the hypothesis, clearly the hypothesis is rejected.

Hypothesis \#4. Differences between PrPT and PoPT for odds, ambiguity and preference for sure bets will be greatest with younger subjects, in the direction of increased risk taking, and differences will decrease with increased age. Pre-program and post-program test scores for odds, ambiguity and preference for sure bets are presented in Table VI in terms of three age groups; thirty years and under, thirty-one to fifty years, and fifty-one years and older. The letters $A_{1}$ and $A_{2}$ refer to the mean odds scores for PrPT and PoPT respectively; $B_{1}$ and $B_{2}$ represent amb1guity in PrPT and POPT; and $C_{1}$ and $C_{2}$ refer to preference for sure bets in PrPT and PoPT.

TABLE VI

MEAN RISK SCORES BY AGE FOR PrPT AND POPT

\begin{tabular}{llllllll}
\hline & $\mathrm{A}_{1}$ & $\mathrm{~A}_{2}$ & $\mathrm{~B}_{1}$ & $\mathrm{~B}_{2}$ & $\mathrm{C}_{1}$ & $\mathrm{C}_{2}$ \\
\hline & & & & & & & \\
\hline 30 and under & 72.41 & 72.29 & 41.55 & 38.47 & 4.53 & 3.71 \\
$31-50$ & 70.81 & 62.46 & 44.73 & 40.35 & 5.58 & 4.31 \\
51 and aver & 72.12 & 67.77 & 40.59 & 38.35 & 4.53 & 4.18 \\
\hline
\end{tabular}


The differences between PrPT and PoPT in odds, amb1guity and preference for sure bets for the thirty years and under group were not significant. For the thirty-one to fifty years age group the PrPT and PoPT scores were signif1cantly different for all measures of risk, with the changes in the direction of increased risk taking. The difference for odds was 8.347, $t=2.906, d f=25, p<.01$; for ambiguity the difference was $4.385, t=3.246$, df $=25, p<.001$; for preference for sure bets the difference was 1.269, $t=2.741, \mathrm{df}=25, \mathrm{p}<.01$. Only in the odds measure did the fifty-one years and older group change significantly, $t=2.093$, df $=16, p<.05$. For both ambiguity and preference for sure bets differences were not significant. The $t$ test for related measures was used in the foregoing analysis.

There were also no signiflcant differences between the three age groups in terms of the mean change between PrPT and PoPT using the $t$ test for independent means. Therefore this hypothesis is refected.

Hypothes1s \#5. Risk scores for the age group thirty years and under will be less than scores for thirty-one to fifty years, which will be less than scores for fifty-one years and over.

There were no significant differences between any of the age groups for any of the risk measures in the pre- 
program testing condition. In the post-program testing condition there was a significant difference between the odds scores of age group thirty-one to fifty years and thirty years and under with the former being lower $(t=2.052$, $d f=41, p<.05)$. The hypothesis that younger subjects will advocate greater risks is rejected. The $t$ test for independent means was used in the above analysis.

Hypothesis \#6. Differences between PrPT and PoPT scores for odds, ambigulty and preference for sure bets will Increase as a function of Increased number of days spent participating in the program.

Mean risk scores for odds, amblgulty and preference for sure bets for the three categorles according to days in program are presented in Table VII.

TABLE VII

MEAN RISK SCORES BY DAYS

FOR PrPT AND POPT

\begin{tabular}{llllllll}
\hline & \multicolumn{2}{c}{ Odds } & \multicolumn{2}{c}{ Ambiguity } & \multicolumn{2}{c}{ Preference } \\
& Por Sure Bets \\
\hline & PrPT & PoPT & PrPT & PoPT & PrPT & PoPT \\
\hline $\begin{array}{l}\text { 21 days } \\
\text { and less }\end{array}$ & 71.0 & 70.6 & 47.9 & 44.0 & 6.6 & 5.7 \\
$\begin{array}{l}\text { 22-28 days } \\
\begin{array}{l}29 \text { days } \\
\text { or more }\end{array}\end{array}$ & 73.0 & 68.1 & 41.9 & 39.2 & 4.7 & 3.8 \\
\hline
\end{tabular}


There are no significant differences between PrPT and PoPT for any of the risk measures in the days category twenty-one days or less. For the days in program category twenty-two to twenty-eight days, there were significant differences between PrPT and PoPT for odds $(t=2.755, d f=29$, $\dot{p}<.01)$ and ambiguity $(t=2.257, d f=29, p<.05)$ but not for preference for sure bets. All differences in the twentynine days and over category were significant: odds, $t=2.118, \mathrm{~d} f=18, \mathrm{p}<.05 ;$ amb1gu1ty, $t=3.416, \mathrm{df}=18$, $p<.01 ;$ preference for sure bets, $t=1.830, \mathrm{df}=18$, $p<.05$. The $t$ test for related measures was used in the above.

Analysis of the mean change scores for each of the three groups revealed no significant differences in terms of any one group changing to a greater degree than any other. The $t$ test for-independent means was used in each case for a one talled, .05 level of significance.

Although there seems to be movement towards increasingly significant differences as a function of days in the program, the magnitude of the differences is not significant and therefore the hypothesis is rejected.

Hypothesis \#7. There will be no significant differerences between men and women for odds, ambiguity, or preference for sure bets in elther the pre or post-program testing scores. 
Table VIII presents the risk scores for men and women In the PrPT and PoPT testing conditions. There are no significant differences for either ambiguity or odds in either testing condition. For odds there were no significant differences in the post-program testing condition, but there is a significant difference in the pre-program testing cond1tion, $t=2.326, \mathrm{~d} f=58, \mathrm{p}<.05$. The hypothesis is generally accepted.

\section{TABLE VIII}

MEAN RISK SCORES FOR MEN AND WOMEN.
IN PRPT AND POPT

\begin{tabular}{|c|c|c|c|c|c|c|}
\hline & \multicolumn{2}{|c|}{ odds } & \multicolumn{2}{|c|}{ Ambiguity } & \multicolumn{2}{|c|}{$\begin{array}{l}\text { Preference } \\
\text { For Sure Bets }\end{array}$} \\
\hline & Men & Women & Men & Women & Men & Women \\
\hline PrPT & 69.49 & $79 \cdot 38$ & $42 \cdot 3$ & 44.15 & 4.96 & 5.08 \\
\hline POPT & 65.09 & 72.76 & $39 \cdot 3$ & 38.46 & 4.19 & 3.77 \\
\hline
\end{tabular}

Hypothesis \#8. There will be no significant differences between men and women for odds, ambiguity and preference for sure bets in terms of amount of change between PrPT and PoPT.

The mean amount of change between PrPT and PoPT for men and women is presented in Table IX. There are no 
significant differences, for any of the risk measures, between men and women. Therefore this hypothesis is accepted.

TABLE IX

MEAN CHANGE FOR MEN AND WOMEN

BETWEEN PrPT AND POPT

\begin{tabular}{lccc}
\hline & Odds & Ambiguity & $\begin{array}{c}\text { Preference For } \\
\text { Sure Bets }\end{array}$ \\
\hline Women & 6.62 & 5.69 & 1.31 \\
Men & 4.40 & 3.00 & .77 \\
\hline
\end{tabular}

\section{Section 2}

Each of the variables age, sex, MMPI scores and days in program were also analyzed in terms of attendance at the out-patient clinics.

Age. Two measures were used to determine if age was a factor in attendance at the out-patient clinics. The first was the mean age of the two groups. The mean age for the follow-up group was 43.48 . The mean age of the non follow-up group was 39.65 . The difference is 3.83 , but is not statistically significant.

The second measure for age was frequency of subjects in each age category attending the clinics. In the thirty and under category 29 per cent (five of seventeen) attended 
follow-up. In the thirty-one to fifty category, 34 per cent (nine of twenty-six) attended follow-up. In the fifty-one and over category 55 per cent (nine of seventeen) attended follow-up. Testing for statistical signiflcance was not done due to time Iimitations. However, the data suggest that increased age was related to increased attendance. Further study seems warranted.

Sex. The number of women subjects attending followup was $\operatorname{six}(N=13)$, which represents 46 per cent of the female sample. The number of men attending the out-patient clinics was seventeen out of forty-seven, or 36 per cent. There appears to be a tendency on the part of the women subjects to attend out-patient clinics more often than men. Statistical analysis was not conducted however, and this conclusion is made with caution.

MMPI Scale Scores. The percentage of subjects attending the out-patient clinics for the two MMPI groups was: Low defensiveness/anxiety $=18.7$ per cent, (three of sixteen); high defensiveness/anxiety $=37.4$ per cent, (three of eight).

Analysis was not done die to time limitations and the small N. Again, detailed analysis with larger samples may yteld signiflcant results.

Days in Program. The mean number of days in the treatment program for the follow-up group was 27.48 . The 
mean number of days for the NFU group was 25.51 . The difference is 1.97 and not significant. The percentage of subjects attending FU for each day's category group is: 27.2 per cent for twenty-one days or less, (three of eleven); 40 per cent for twenty-two to twenty-eight days, (twelve of thirty); and 42.1 for twenty-nine days and over (elght of nineteen). Although not analyzed statistically, the data appear to indicate that length of time spent in program is a factor in attendance at the out-patient clinics.

Section 3

The hypothesis that the FU group would have larger changes than the NFU group was supported both in terms of changes within each group and differences between amount of change between groups. The FU group changed significantly in all measures of risk and changed in a signiflcantly larger amount than the non follow-up group. The NFU group did not change significantly between the two testing cond1tions.

The second hypothesis, that the follow-up group would have scores which would indicate greater willingness to risk, greater tolerance of ambiguity and lower preference for sure bets was not supported. There were no significant differences between FU and NFU groups for any of the risk measures, for PoPT. That 1s, at the end of the program all 
of the subjects were scoring the same on the risk measures and presumably willing to "risk" at the same level. The only pair of scores which were signiflcantly different between the two groups was the odds scores in the PrPT cond1tion. The question then arises, that if there are virtually no significant differences between the two groups in both testing conditions, where do the differences in change scores come from? Table $X$ presents the scores for both groups in terms of the sequence high scores to low scores.

TABLE X

RISK SCORES FOR FU AND NFU GROUPS IN SEQUENCE

\begin{tabular}{lccc}
\hline & A & B & C \\
\hline FU GROUP/Pre & 75.61 & 44.22 & 5.65 \\
NFU GROUP/Pre & 68.75 & 41.69 & 4.47 \\
NFU GROUP/POst & 66.78 & 39.86 & 4.33 \\
FU GROUP/Post & 66.42 & 38.70 & 4.04 \\
\hline
\end{tabular}

The FU group in each case started from a position of greater conservatism yet arrived at a score by the end of program which was virtually the same as the NFU group. The NFU occupled the middle of the progression such that the differences between both the pre and post-program testing 
was not large, but the differences within the groups between pre and post-program testing was significant for the FU group.

The major difference between the two groups was not riskyness, tolerance of ambiguity or preference for sure bets at the end of the program, but the amount of change that occurred on these measures between the testing dates. One explanation for the above data would be in terms of the reinforcement value of change. The individual who changes, in a positive direction, using a specific technique is going to be more likely to use that same technique to induce further change. For example, a golfer finds that instruction of a particular kind improves his game by 20 per cent. Another golfer using the same technique, improves oniy 5 per cent; such that at the end of the instruction both golfers are playing at the same level. The improvement is reinforcing of the type of instruction used and logicaliy the extent of improvement will be a factor in the extent of the reinforcement. Therefore, should the two golfers declde, in the future, to seek further instruction, the individual who changed the most is going to be more likely to use the same kind of instruction than the individual who changed the least.

With the alcoholics, the increased capacity or tolerance of risk taking would correspond to a reduction in "fear 
of fallure." Those subjects who experienced the greatest reduction in "fear of failure" will need to relate this change to the experiences of program and probably the therapeutic strategy, used in the program. Therefore, when faced with the option of particlpating in an out-patient situation using a similar strategy, the subjects achieving the greatest benefit or change would most likely choose to continue. Those subjects who felt little change would find little reason to participate, because that particular technique has not proved useful so far.

A second explanation might be that the large change from relative conservatism and structuredness to a position of less structure or more risk leaves the individual in a new and somewhat uncomfortable position. The new position Is more uncomfortable for the subjects who changed the most because it is further removed from the old position and therefore more aspects require integration. The uncomfortableness of the new position is therefore a function of the lack of familiarity of the new behavior and feelings. Although these new feelings and actions may be more adaptive and satisfying, they are nonetheless unfamiliar and therefore could produce some anxlety.

It may also be that the out-patient clinic serves as a source of security and support for these individuals. Attending groups at the out-patient clinics could provide 
an atmosphere where the Individual would recelve continued support and reinforcement for new behavior as well as a place where difficulties could be discussed and worked through. The out-patient clinic might thus provide a temporary structure for the individual while he restructures or integrates the new perceptions, feelings and behaviors.

It is also possible that these phenomena could be working simultaneously. For the individual who is seeking to continue the growth process, or just to maintain the growth or change already made; the cholce of attending the out-patient clinic could be one using a proven technique because it is supportive and helps solve problems.

Clearly the hypothesis that high defensiveness and anxiety would yleld smaller changes on the risk measures than low defensiveness and anxiety was not supported. There is even some data that suggests that the reverse conclusion might be more accurate. It seems reasonable, in hindsight, that given a motivation to change, those individuals suffering the most (high defensiveness and anxiety) will be the ones most eager to reduce this suffering; that is, change.

Even if the data had been conclusive, there would be a problem in interpretation due to a methodological oversight. In the Kogan and Wallach (1964) study from which this hypothesis was derived, the risk-taking data was collected within a few days of psychological testing. Therefore it is 
valid to conclude that the psychological data was representative of the subjects while they were undergoing the risktaking experiments. In the present study--for most subjects-over three weeks passed from beginning to completion of the risk-taking study. It is unknown whether or not a particular subject who scored in the high defensiveness/anxiety range on admission, would still score in that range three or four weeks later when the second risk-taking questionnaire was administered. To test the hypothesis as stated, one would need to know the defensiveness/anxiety scores at the time of both risk-taking test conditions.

The hypothesis that length of stay in the program would increase the amount of change between testing conditions was supported in part by the increasing progression of statistically significant results. There were no significant differences for any of the risk measures in the twentyone days or less category. In the twenty-two to twentyeight days category, two measures produced significant differences, odds and ambiguity. In the third category, twenty-nine days and over, all three measures yielded. signifieant differences.

However, the critical factor for this hypothesis was the extent or degree of change. When the average degree of change for each risk measure was compared with the different categories, there were no signiflcant differences (see Table VII). 
Age seemed to have an effect on change scores, but not In the predicted manner. Rather than the youngest subjects showing the greatest change, the middle (thirty-one to fifty) group changed the most and was the only group that changed significantly in all measures of risk. The only other significant change was in the fifty-one and older group, for odds. AII change scores for the youngest group and for the other two measures in the fifty-one and over group were nonsigniflcant. The numerical value of the scores were also nonsigniflcart for all measures in PrPT and all but one in PoPT. That is, there were no significant differences between scores in PrPT and the only significant difference in PoPT was between thirty and under and thirtyone to fifty-one, with thirty-one to fifty-one being riskier.

The hypothesis that the sex of subjects would not be a factor in elther the numerical values or the extent of change was largely supported. In only one instance was there a significant difference for elther numerical values or mean change scores.

\section{Summary of Results}

1. Attendance at the out-patient clinics was related to change in risk-taking scores from admission to discharge. All measures of risk showed positive changes that were statistically significant. 
2. Discharge or post-program test scores did not predict attendance at the out-patient clinics.

3. There are no major differences between risk scores with age as a variable. The time frame thirty-one to fifty years did appear to show the greatest potential for change in risk taking. Age does not seem to be a clear factor in attendance at the out-patient clinics.

4. Again, there is no clear difference between risktaking scores of men and women. Sex does not appear to be a significant factor in attendance at the out-patient clinics. Further study with a larger female sample may prove different, because the women attended 10 per cent more often than did the men. Sex, however, may be a factor in attendance at the out-patient clinics. Further study seems warranted.

5. High defensiveness/anxiety did not yleld smaller change scores than did low defensiveness/anxiety.

6. There was an increase in a number of significant differences as a function of increased number of days in the treatrient program. There were, however, no significant differences between FU and NFU groups in terms of average number of days in the program, nor were the mean change scores significantly different. 
CHAPTER V

\section{CONCLUSION}

Research Difficulties

There are two major problems with this research in terms of interpreting the results and coming to any conclusions. The use of attendance at the out-patient clinics as a measure of change is the first. The measure does not lack valldity, it just does not provide enough data on how the client is functioning after discharge. Clearly, a more comprehensive follow-up would be useful and should include further testing of the client's risk-taking propensities. The second problem involves the use of the same instrument to derive the three different measures of risk taking. Other research in this area would want to use measures of odds, ambiguity and preference for sure bets that are independent of each other so as to determine situational and personal differences.

Recommendations for Further Research

There is need for continued research in three general areas. The first is in terms of determining the relationships between the three risk measures in different situatIonal contexts. For example, are there risk-taking 
situations which tend to ellcit high preferences for extreme odds and a low tolerance for ambigulty?

A second area of research might be to relate the risktaking attitudes of different groups to one another. For example, how does the hospltalized alcoholic's perception of risk compare with that of a non drinking out-patient, or with that of a "cured" alcoholic? Do alcoholics view risk from the same perspective as do depressives, hysterics, etc.? Additionally, the relationships of risk taking and age are not clear. Why did the thirty-one to fifty year old age group change more than the younger and presumably more flexible subjects? How do alcoholics compare with soclal drinkers and non drinkers in terms of the three measures of risk? Would risk-taking attitudes change in different kinds of therapeutic situations; for example, behavior modification versus gestalt? And if so, in what ways?

A third area of research might be to compare risk taking to other kinds of behavior. Specifically, follow-up studies where the criteria for change are more comprehensive might be done.

\section{Implications}

If continuing in the therapeutic process is a goal in treatment, then, based on the data presented in this study, one of the major areas of emphasis suggested would be in 
giving the client feedback as to whether or not he was changing in the desired direction. It appears that relatively large changes are rewarding by themselves. Small changes, however, may require an outside source of reinforcement in order for the client to feel sufficlently rewarded. Systems need to be developed whereby the client and staff can determine if change has occurred, and if the change is percelved as positive by the client and the staff. Additionally there needs to be ways of reporting and rewardIng the new behavior. Development, and especially the conduct, of such a program would be no easy task. Such an effort would require specific goals, specification of behavioral criteria, methods of quantification, and most of all, time.

Two other implications can cautiousiy be drawn from the data in terms of models of treatment leading to attendance at out-patient clinics. One is that there seems to be a period of time when the alcoholic is potentially more susceptible to change in his risk-taking attitudes and possibly to change in a number of other areas. While the middle age category changed most, the fifty-one and over category had the highest rate of attendance. The youngest group, on the other hand, changed least and had the lowest rate of attendance. It may be that people with drinking problems who are relatively young are not ready emotionally to change. For 
these individuals other forms of therapy may be more effective. A second implication for treatment is that individuals who did not remain in treatment for at least three weeks were less likely to attend the out-patient clinics. Alcoholics are experts at creating emergencies which would recommend an early discharge, yet it may be that not remainIng in the treatment program for the required length of time is prejudicial to successful treatment. 


\section{A SELECTED BIBLIOGRAPHY}

Atkinson, J.; J. Bastion; R. Earl; and G. Iltwin. The Achlevement Motive Goal-Setting and Probability Preferences. Journal of Abnormal Psychology, 1960, 60, $27-36$.

Bateson, G. Cybernetics of Self: A Theory of Alcoholism. Psychiatry, 1971, 34, 1-18.

Berne, E. Games People Play. New York: Grove Press, 1964.

Bruning, J. and B. Kintz. Computational Handbook of Statistics. Glenview, Iilinois: Scott, Foresman, I968.

Cahalan, D.; I. Clsin; and H. Crossely. American Drinking Practices. New Brunswick, N.J.: Rutgers Center of Alcohol Studies, 1969.

Cohen, J. Chance, Sk11l and Luck. Baltimore: Penguin, 1960 .

Coleman, J. and W. Broen. Abnormal Psychology and Modern Life. Glenview, Illinols: Scott, Foresman, 1972.

Conger, J. Reinforcement Theory and the Dynamics of Alcoholism. Quarterly Journal of Studies on Alcohol, $1956,17, \frac{17}{296-305 .}$

Dahlstrom, W. and G. Welsh. An MMPI Handbook: A Gulde to Use in Clinical Practice and Re search. Miñneapolis: University of Minnesota press, 1960.

Dav1s, C. The Human Equation. Malvern News, 1962, 1, 1 .

Dollard, J. and N. Miller. Personality and Psychotherapy. New York: McGraw-Hill, 1950.

Edwards, W. Probability Preferences in Gambling. American Journa1 of Psychology, 1953, 66, 349-364.

Edwards, W. Probability Among Bets With Different Expected Values. American Journal of Psychology, 1954a, 67, $56-67$. 
Edwards, W. The Reliabllity of Probability Preferences. American Journal of Psychology, 1954b, 67, 67-95.

Edwards W. Varlance Preferences in Gambling. American Journal of Psychology, 1954c, 67, 441-452.

Ehlers, T. Alkohol-Bedingre Motivation San Derung und Unfallgef Ahrdung. In P. Hurst, Effects of Alcohol on Mood and Volition. Psychological Reports, 1969. 24, 975-987.

Enright, J. An Introduction to Gestalt Therapy Techniques . In J. Fagan and I. Shepherd (Eds.) Gestalt Therapy Now. New York: Harper, 1970, pp. 107-139.

Eysenck, $H$. The Biological Basis of Personality. Springfield, IIInnois: Thomas, 1967.

Fenichal, 0. The Psychoanalytic Theory of Neuroses. New York: W. W. Norton, 1945.

Frenkel-Brunswick, E. Intolerance of Ambiguity as an Emotional and Personality Variable. Journal of Personal1ty, 1949, 18, 108-143.

Gerard, D. and G. Saenger. Out-Patient Treatment of Alcoholism. Toronto: Brookside Monographs, I966.

Hamilton, V. Perceptual and Personality Dynamics in Reactions to Ambiguity. British Journal of Psychology, $1957,48,200-215$.

Hurst, P. Effects of Alcohol on Mood and Volition. Psychological Reports, 1969, 24, 975-987.

Ka1j, L. Alcoholism in Twins: Studies on the Etiology And Sequels and Abuse of Alcohol. Stockholm: Almquist and Wiksel1, 1960 .

Karp, S.; H. Witkin; and D. Goodenough. Alcohollsm and Psychological Differentiation: Long-range Effect of Heavy Drinking on Field Dependence. Journal of Nervous and Mental D1sease, 1965,140 (6), $412-416$.

Katz, L. Monetary Incentive and Range of Payoffs as Determiners of Risk Taking. Journal of Experimental Psychology, 1962, 64, 541-544. 
Kinsey, B. The Female Alcoholic. Springfield, Illinols: Thomas, 1966 .

Kogan, N. and M. Wallach. Risk Taking as a Function of the Situation, the Person, and the Group. In New Directions in Psychology III. New York: Holt, Rinehart and Winston, 1967, pp. 113-266.

Kogan, N. and M. Wallach. Risk Taking: A Study in Cognition and Personality. New York: Holt, Rinehart and Winston, 1964 .

Krause, H. Ethical Risk Taking Among Alcoholics. Quarterly Journal of Studies on Alcohol, 1971, 32, 775-781.

Lester, D. Self-Selection of Alcohol by Animals, Human Variation, and the Etiology of Alcoholism. Quarterly Journal of Studies on Alcohol, 1966, 27, 395-438.

Littig, L. Effects of Motivations on Probability Preferences. Journal of Personality, 1963, 31, 417-427.

MacAndrew, C. and R. Edgerton. Drunken Comportment. Chicago: Aldine, 1969.

Martin, B. Intolerance of Ambiguity in Inter-Personal and Perceptual Behavior. Journal of Personality, 1953, 22 494-503.

Maslow, A. Toward a Psychology of Being. New York: Van Nostrand Reinhold, 1968.

McClearn, G. and D. Rogers. Differences in Alcohol Preference Among Inbred Strains of Mice. Quarterly Journal of Studies on Alcohol, 1959, 20, 691-695.

McClelland, D. C.; R. Atkinson; R. Clark; and E. Lowell. The Achievement Motive. New York: Appleton, 1953.

McCord, W.; J. McCord; and D. Gudeman. Oxigins of Alcohol1sm. Stanford: Stanford University Press, 1960.

McKinlay, A. The Roman Attitude Toward Women's Drinking. Classical Bulletin, 22, 14-15.

Menninger, K. The Vital Balance. New York: Viking Press, 1963 . 
Meyer, H.; W. Walker; G. Iitwin. Motive Patterns and Risk Preferences Associated W1th Entrepreneurship. Journal of Abnormal and Social Psychology, 1966, 63, 570-574.

Mulford, K. and D. Miller. Drinking in Iowa, IV. Quarterly Journal of Studies on Alcohol, 1960, 21, 279-291.

Myers, J. and E. Sadler. Effects of Range of Payoffs as a Variable in Risk Taking. Journal of Experimental Psychology, 1960, 60, 306-309.

Nash, T. Plerce Peniless, His Supplication to the Divell, 1592. Reprinted in Quarterly Journal of Studies on Alcohol, 1943-1944, 4, 462-469.

Partanan, J.; K. Brunn; and T. Makkanan. Inheritance of Drinking Behavior. Helsinki: The Finnish Foundation for Alcohol Studies, 1966.

Polster, I. and M. Polster. Gestalt Therapy Integrated. New York: Brunner Mazel, 1973.

Pruitt, D. Pattern and Level of Risk in Gambling Decisions. Psychological Review, 1962, 69, 187-201.

Raynor, J. and C. Smith. Achievement-Related Motives and Risk Taking in Games of Skill and Chance. Journal of Personal1ty, 1966, 34, 176-198.

Rettig, S. and H. Rawson. The Risk Hypothesis in Predictive Judgements of Unethical Behavior. Journal of Abnormal and Social Psychology, 1963, 66, 243-248.

Roebuck, J. and R. Kessler. The Etlology of Alcoholism. Springfield, Illinois: Thomas, 1972 .

Rogers, L. Metabolic Characteristics of Alcoholics. Quarterly Journal of Studies of Alcohol, 1959, 20, 33-37.

Rotter, J. Generalized Expectancies for Internal Versus External Control of Reinforcement. Psychological Monographs, 1966, 80, 476-483.

Rule, B. and D. Besier. Level of Risk Advocated by Alcoholics. Psychological Reports, 1970, 27, 829-830.

Rush, B. An Inquiry Into the Effects of Ardent Spirits Upon the Human Body and Mind. 6th ed. New York, 1811. 
Sadoun, R.; G. Lolli; and M. Silverman. Drinking in French Culture. New Brunswick, N.J.: Rutgers Center of Alcohol Studies, 1965.

Sapir, J. Social Work and Alcoholism. The Annals of The American Academy, 1958, 315, pp. 125-132.

Smock, c. The Influence of Psychological Stress on the Intolerance of Ambiguity. Journal of Abnormal Social Psychology, 1955a, 50, 177-182.

Snyder, c. Alcohol and the Jews. Glencoe: The Free Press, 1958.

Steiner, C. The Alcholic Game. Quarterly Journal of Studies on Alcohol, 1969, 30, 920-938.

Stelner, C. Games Alcoholics Play. New York: Grove, 1971.

Suydam, M. and J. Meyers. Some Parameters of Risk-Taking Behavior. Psychological Reports, 1962, 10, 559-562.

Tamerin, J. and J. Mendelson. The Psychodynamics of Chronic Inebriation. American Journal of Psychiatry, 1969. 125, 886-899.

Teger, A.; E. Katkin; and D. Pruitt. Effects of Alcoholic Beverages and Their Congener Content on Level and Style of Risk Taking. Journal of Personality and Social Psychology, 1969, $11,170-175$.

Tintera, J. Office Rehabilitation of the Alcoholic. New York State Journal of Medicine, 1956, 56, 3896-3902.

Wertheim, J. and S. Mednick. The Achievement Motive and Field Independence. Journal of Consulting Psychology, $1958,22,38$.

Williams, R. Alcoholism: The Nutritional Approach. Austin: The University of Texas Press, 1959.

Witkin, H.; S. Karp; and D. Goodenough. Personality Through Perception. New York: Harper and Brothers, 1954. 


\section{APPENDIX A}

CHOICE DILEMMAS PROCEDURE

\section{OPINION QUESTIONNAIRE}

Instructions. On the following pages, you will find 2 series of situations that are likely to occur in everyday 11fe. The central person in each situation is faced with a cholce between two alternative courses of action, which we might call $X$ and $Y$. Alternative $X$ is more desirable and attractive than alternative $Y$, but the probability of attalning or achieving $X$ is less than that of attaining or achieving $Y$.

For each situation on the following pages, you will be asked to indicate the minimum odds of success you would demand before recommending that the more attractive or desirable alternative, $x$, be chosen.

Read each situation carefully before giving your judgment. Try to place yourself in the position of the central person in each of the situations. There are twelve situations in all. Please do not omit any of them.

1. Mr. A, an electrical engineer, who is married and has one chlld, has been working for a large electronics 
corporation since graduating from college five years ago. He is assured of a lifetime job with a modest, though adequate salary, and liberal pension benefits upon retirement. on the other hand, it is very unlikely that his salary will increase much before he retires. While attending a convention, Mr. A is offered a job with a small, newly founded company which has a highly uncertain future. The new job would pay more to start and would offer the possibility of a share in the ownership if the company survived the compet1tion of the larger firms.

Imagine that you are advising Mr. A. Listed below are several probabilities or odds of the new company's proving financlaliy sound.

Please check the lowest probability that you would consider acceptable to make it worthwhile for $\mathrm{Mr}$. A to take the new job.

The chances are 1 in 10 that the company will prove financially sound.

The chances are 3 in 10 that the company will prove financially sound.

The chances are 5 in 10 that the company will prove financially sound.

The chances are 7 in 10 that the company w1ll prove financlally sound.

The chances are 9 in 10 that the company w1ll prove financially sound.

Place a check here if you think Mr. A should not take the new Job no matter what the probabilities. 
2. Mr. B, a 45-year-old accountant, has recently been Informed by his physician that he has developed a severe heart alment. The disease would be sufficlently serious to force $\mathrm{Mr}$. B to change many of his strongest life habits-reducing his work load, drastically changing his diet, giving up favorite lelsure-time pursuits. The physician suggests that a delicate medical operation could be attempted which, if successful, would completely relleve the heart condition. But its success could not be assured, and in fact, the operation might prove fatal.

Imagine that you are advising Mr. B. Iisted below are several probabilities or odds that the operation w11l prove successful.

Please check the lowest probability that you would consider acceptable for the operation to be performed. Place a check here if you think Mr. B should not have the operation no matter what the probabilities.

The chances are 9 in 10 that the operation w1ll be a success.

The chances are 7 in 10 that the operation will be a success.

The chances are 5 in 10 that the operation w1ll be a success.

The chances are 3 in 10 that the operation will be a success.

The chances are 1 in 10 that the operation w1ll be a success. 
3. Mr. C, a married man with two children, has a steady job that pays him about $\$ 6000$ per year. He can easily afford the necessities of 1ife, but few of the luxurles. Mr. C's father, who died recently, carried a $\$ 4000$ IIfe insurance policy. Mr. C would like to invest this money in stocks. He is well aware of the secure "blue-chip" stocks and bonds that would pay approximately $6 \%$ on his investment. On the other hand, $M r$. $C$ has heard that the stocks of a relatively unknown Company $\mathrm{X}$ might double their present value if a new product currently in production is favorably received by the buying public. However, if the product is unfavorably received, the stocks would decline in value.

Imagine that you are advising $M r$. C. Iisted below are several probabilities or odds that Company $X$ stocks will double their value.

Please check the lowest probability that you would consider acceptable for $\mathrm{Mr}$. C to invest in Company $\mathrm{X}$ Stocks. The chances are 1 in 10 that the stocks will double their value.

The chances are 3 in 10 that the stocks will double their value.

The chances are 5 in 10 that the stocks will double their value.

The chances are 7 in 10 that the stocks will double their value.

The chances are 9 in 10 that the stocks will double their value. 
Place a check here if you think Mr. C should not invest in Company $X$ stocks, no matter what the probabilities.

4. Mr. D 1s the captain of College X's football team. College $X$ is playing its traditional rival, College $Y$, in the final game of the season. The game is in its final seconds, and Mr. D's team, College $X$, is behind in the score. College $\mathrm{X}$ has time to run one more play. Mr. D, the captain, must decide whether it would be best to settle for a tie score with a play which would be almost certain to work, or on the other hand, should he try a more complicated and risky play which could bring victory if it succeeded, but defeat if not.

Imagine that you are advising Mr. D. Listed below are several probabilities or odds that the risky play will work.

Please check the lowest probability that you would consider acceptable for the risky play to be attempted.

Place a check here if you think Mr. D should not attempt the risky play no matter what the probabilities.

The chances are 9 in 10 that the risky play will work.

The chances are 7 in 10 that the risky play will work.

The chances are 5 in 10 that the risky play will work.

The chances are 3 in 10 that the risky play will work.

The chances are 1 in 10 that the risky play will work. 
5. Mr. $\mathrm{E}$ is president of a light metals corporation in the United States. The corporation is quite prosperous, and has strongly considered the possibilities of business expansion by bullding an additional plant in a new location. The cholce is between bullding another plant in the U.S., where there would be a moderate return on the initial investment, or building a plant in a foreign country. Lower labor costs and easy access to raw materials in that country would mean a much higher return on the initial investment. On the other hand, there is a history of political Instability and revolution in the forelgn country under consideration. In fact, the leader of a small minority party is committed to nationalizing, that is, taking over, all foreign investments.

Imagine that you are advising $\mathrm{Mr}$. E. Ilsted below are several probabilities or odds of continued political stability in the forelgn country under consideration.

Please check the lowest probabllity that you would consider acceptable for Mr. E's corporation to build a plant in that country.

The chances are 1 in 10 that the forelgn country will remain politically stable.

The chances are 3 in 10 that the forelgn country will remain politicaliy stable.

The chances are 5 in 10 that the forelgn country will remain politically stable. 
The chances are 7 in 10 that the forelgn country will remain politically stable.

The chances are 9 in 10 that the forelgn country will remain politically stable.

Place a check here if you think Mr. E's corporation should not build a plant in the forelgn country, no matter what the probabilities.

6. Mr. F is currently a college senior who is very eager to pursue graduate study in chemistry leading to the Doctor of Philosophy degree. He has been accepted by both University $X$ and University $Y$. University $X$ has a worldwide reputation for excellence in chemistry. While a degree from University $X$ would signify outstanding training in this field, the standards are so very rigorous that only a fraction of the degree candidates actually recelve the degree. University $Y$, on the other hand, has much less of a reputation in chemistry, but almost everyone admitted is awarded the Doctor of Philosophy degree, though the degree has much less prestige than the corresponding degree from University $x$. Imagine that you are advising Mr. F. Listed below are several probabilities or odds that Mr. F would be awarded a degree at University $x$, the one with the greater prestige.

Please check the lowest probability that you would consider acceptable to make it worthwhlle for Mr. F to enroll In University $X$ rather than University $Y$. 
Place a check here if you think Mr. F should not enroll in University $x$, no matter what the probabilities.

The chances are 9 in 10 that $\mathrm{Mr}$. F would recelve a degree from University $X$.

The chances are 7 in 10 that $M r \quad F$ would recelve a degree from University $X$.

The chances are 5 in 10 that $\mathrm{Mr}$. F would recelve a degree from University $X$.

The chances are 3 in 10 that $\mathrm{Mr}$. F would recelve a degree from University $X$.

The chances are 1 in 10 that $M r . F$ would recelve a degree from University $X$.

7. Mr. G, a competent chess player, is particlpating in a national chess tournament. In an early match he draws the top-favored player in the tournament as his opponent. Mr. G has been given a relatively low ranking in view of his performance in previous tournaments. During the course of his play with the top-favored man, Mr. G notes the possibi11ty of a deceptive though risky maneuver which might bring him a quick victory. At the same time, if the attempted maneuver should fail, $\mathrm{Mr}$. G would be left in an exposed position and defeat would almost certainly follow.

Imagine that you are advising Mr. G. Iisted below are several probabilities or odds that $\mathrm{Mr}$. G's deceptive play would succeed.

Please check the lowest probability that you would consider acceptable for the risky play in question to be attempted. 
The chances are $I$ in 10 that the play would succeed. The chances are 3 in 10 that the play would succeed. The chances are 5 in 10 that the play would succeed. The chances are 7 in 10 that the play would succeed. The chances are 9 in 10 that the play would succeed. Place a check here if you think Mr. G should not attempt the risky play, no matter what the probabilities.

8. Mr. H, a college senior, has studied the piano since childhood. He has won amateur prizes and given small recitals, suggesting that $M r$. H has considerable musical talent. As graduation approaches, Mr. H has the cholce of going to medical school to become a physician, a profession which would bring certain prestige and financial rewards; or entering a conservatory of music for advanced training with a well-known planist. Mr. H realizes that even upon completion of his plano studies, which would take many more years and a lot of money, success as a concert pianist would not - be assured.

Imagine that you are advising Mr. H. Iisted below are several probablilties or odds that $\mathrm{Mr}$. H would succeed as a concert planist.

Please check the lowest probabllity that you would consider acceptable for $\mathrm{Mr}$. H to continue with his musical training. 
Place a check here if you think $\mathrm{Mr}$. H should not pursue his musical training, no matter what the probabilities.

The chances are 9 in 10 that $M r$. H would succeed as a concert pianist.

The chances are 7 in 10 that $\mathrm{Mr}$. $\mathrm{H}$ would succeed as a concert pianist.

The chances are 5 in 10 that $\mathrm{Mr}$. H would succeed as a concert pianist.

The chances are 3 in 10 that $\mathrm{Mr}$. $\mathrm{H}$ would succeed as a concert pianist.

The chances are 1 in 10 that $\mathrm{Mr}$. $\mathrm{H}$ would succeed as a concert pianist.

9. Mr. J is an American captured by the enemy in World War II and placed in a prisoner-of-war camp. Conditions in the camp are quite bad, with long hours of hard physical labor and a barely sufficient diet. After spending several months in this camp, Mr. J notes the possibility of escape by concealing himself in a supply truck that shuttles In and out of the camp. Of course, there is no guarantee that the escape would prove successful. Recapture by the enemy could well mean execution.

Imagine that you are advising Mr. J. Listed below are several probabilities or odds of a successful escape from the prisoner-of-war camp.

Please check the lowest probability that you would consider acceptable for an escape to be attempted. 
The chances are 1 in 10 that the escape would succeed.

The chances are 3 in 10 that the escape would succeed.

The chances are 5 in 10 that the escape would succeed.

The chances are 7 in 10 that the escape would succeed.

The chances are 9 in 10 that the escape would succeed.

Place a check here if you think Mr. J should not try to escape no matter what the probabilities.

10. Mr. $\mathrm{K}$ is a successful businessman who has particlpated in a number of civic activities of considerable value to the community. Mr. $K$ has been approached by the leaders of his political party as a possible congressional candidate in the next election. Mr. K's party is a minority party in the district, though the party has won occasional elections in the past. Mr. $K$ would like to hold political offlce, but to do so would involve a serious financial sacrifice, since the party has insufficient campaign funds. He would also have to endure the attacks of his political opponents in a hot campaign.

Imagine that you are advising Mr. K. Listed below are several probabilities or odds of Mr. K's winning the election in his district. 
Please check the lowest probability that you would consider acceptable to make 1 t worthwhile for $\mathrm{Mr}$. K to run for political office.

Place a check here if you think Mr. K should not run for political office no matter what the probabilities.

The chances are 9 in 10 that $M r \quad K$ would win the election.

The chances are 7 in 10 that $\mathrm{Mr}$. $\mathrm{K}$ would win the election.

The chances are 5 in 10 that $\mathrm{Mr}$. $\mathrm{K}$ would win the election.

The chances are 3 in 10 that $\mathrm{Mr}$. $\mathrm{K}$ would win the election.

The chances are 1 in 10 that $M r ~ K$ would win the election.

11. Mr. L, a married 30-year-old research physicist, has been given a five-year appointment by a major university laboratory. As he contemplates the next five years, he realizes that he might work on a difficult, long-term problem which, if a solution could be found, would resolve basic scientific issues in the field and bring high scientific honors. If no solution were found, however, Mr. I would have little to show for his five years in the laboratory, and this would make it hard for him to get a good job afterwards. On the other hand, he could, as most of his professlonal assoclates are doing, work on a serles of short-term problems where solutions would be easier to find, but where the problems are of lesser scientific importance. 
Imagine that you are advising Mr. I. IIsted below are several probablilties or odds that a solution would be found to the difficult, long-term problem that $\mathrm{Mr}$. I has in mind.

Please check the lowest probability that you would consider acceptable to make it worthwhile for Mr. L to work on the more difficult long-term problem.

The chances are 1 in 10 that Mr. I would solve the long-term problem.

The chances are 3 in 10 that $M r$. I would solve the long-term problem.

The chances are 5 in 10 that $M r$. I would solve the long-term problem.

The chances are 7 in 10 that $\mathrm{Mr}$. I would solve the long-term problem.

The chances are 9 in 10 that $\mathrm{Mr}$. I would solve the long-term problem.

Place a check here if you think Mr. I should not choose the long-term, difficult problem, no matter what the probabilities.

12. Mr. M is contemplating marriage to Miss $T$, a girl whom he has known for a little more than a year. Recently, however, a number of arguments have occurred between them, suggesting some sharp differences of opinion in the way each views certain matters. Indeed, they decide to seek professional advice from a marriage counselor as to whether it would be wise for them to marry. On the basis of these meetings with a marriage counselor, they realize that a happy marriage, while possible, would not be assured. 
Imagine that you are advising $M r . M$ and Miss $T$. Listed below are several probabilities or odds that their marrlage would prove to be a happy and successful one.

Please check the lowest probability that you would consider acceptable for $\mathrm{Mr}$. M and Miss $T$ to get married. Place a check here if you think Mr. M and Miss T should not marry, no matter what the probabilities.

The chances are 9 in 10 that the marrlage would be happy and successful.

The chances are 7 in 10 that the marriage would be happy and successful.

The chances are 5 in 10 that the marriage would be happy and successful.

The chances are 3 in 10 that the marrlage would be happy and successful.

The chances are 1 in 10 that the marriage would be happy and successful. 